Eskişehir Osmangazi Üniversitesi İlahiyat Fakültesi Dergisi Journal of Eskişehir Osmangazi University Faculty of Theology ISSN: 2147-8171

\title{
Memlükler Dönemi Tarih Yazımına Bir Örnek: Ebû Zer Sıbt İbnü’l-Acemî (ö. 884/1480) ve Künûzü’z-Zeheb fî Târîhi Haleb Adlı Eseri
}

An Example of Historiography in The Mamluk Period: Abu Zar Sibt Ibn al-Acami (ö. 884/1480) and His Book's Kunuz az-Zahab fi Tarikh Haleb

\section{Dr. Öğr. Üyesi Esra ATMACA}

Sakarya Üniversitesi, İlahiyat Fakültesi, İslam Tarihi ve Sanatları Anabilim Dalı Asst. Prof., Sakarya Uni., Faculty of Divinity, Department of Islamic History and Arts, Sakarya, Turkey. esraatmaca@sakarya.edu.tr

(iD 0000-0002-5093-3621

Makale Bilgisi / Article Information

Makale Türü / Article Type Araştırma Makalesi / Research Article

Geliş Tarihi / Received

Kabul Tarihi / Accepted

Yayın Tarihi / Published

06 Ocak / January 2021

31 May / May 2021

23 Eylül / September 2021

Atıf Bilgisi / Cite as:

Atmaca, Esra. “Memlükler Dönemi Tarih Yazımına Bir Örnek: Ebû Zer Sıbt İbnü'l-Acemî (ö. 884/1480) ve Künûzü'z-Zeheb fî Târîhi Haleb Adlı Eseri”, Eskişehir Osmangazi Üniversitesi İlahiyat Fakültesi Dergisi 8/2 (Eylül 2021), 12-35.

http://doi.org/1051702/esoguifd.855535

İntihal / Plagiarism: Bu makale, en az iki hakem tarafından incelenmiş ve intihal içermediği teyit edilmiştir. / This article has been reviewed by least two referees and scanned via a plagiarism software.

Copyright @ Published by Eskişehir Osmangazi Üniversitesi, İlahiyat Fakültesi /Eskişehir Osmangazi University, Faculty of Theology Bütün hakları saklıdır. / All right reserved. https://dergipark.org.tr/tr/pub/esoguifd

CC BY-NC 4.0 This paper is licensed under a Creative Commons Attribution-NonCommercial License

Etik Beyanı / Ethical Statement: Bu çalışmanın hazırlanma sürecinde bilimsel ve etik ilkelere uyulduğu, yararlanılan tüm çalışmaların kaynakçada belirtildiği ve bu araştırmanın desteklenmesi için herhangi bir dış fon almadıkları yazar tarafından beyan olunur / It is declared by the author that scientific and ethical principles have been followed while carrying out and writing this study; that all the sources used have been properly cited; that no external funding was received in support of the research. 
Atmaca, An Example of Historiography in the Mamluk Period: Abu Zar Sibt Ibn al-Acami (ö. 884/1480) and ...

\section{Memlükler Dönemi Tarih Yazımına Bir Örnek: Ebû Zer Sıbt İbnü’l-Acemî (ö. 884/1480) ve Künûzü'z-Zeheb fî Târîhi Haleb Adlı Eseri}

Öz • Memlükler dönemi ilmî çalışmaların zirve yaptığı bir dönemdir. Bu çalışmaların daha yoğun olduğu devletin merkezi Kahire'nin yanı sıra Suriye bölgesinde Dımaşk ve Halep’te de önemli ilim adamları yetişmiştir. Onlardan biri de Ebû Zer Sıbt İbnü'l-Acemî el-Halebî'dir. Ebû Zer, devrinin pek çok büyük âliminden ders almış ve yaşadığı dönemde ulemânın önde gelenleri arasında yer almıştır. Ebû Zer'in kaleme almış olduğu eserlerin büyük kısmı kayıp olmasına rağmen Künûzü'z-zeheb fì târîhi Haleb adlı eseri kısmen de olsa günümüze ulaşmıştır. Bu makalede öncelikle Ebû Zer'in hayatı ve eserleri, sonra da Künûzü’z-zeheb adlı eseri tarihçiliği ve muhtevâsı açısından incelenmektedir. Birinci cildi hıtat, ikinci cildi havâdis ve vefeyât ağırlıklı olan, Memlük tarih yazıclığında önemli unsulardan nukât, evâil, el-'acâib ve'l-garâib gibi unsurların hepsini yoğun bir şekilde görmenin mümkün olduğu bu eser, genel hatlarıyla önceki tarihçiler örnek alınmış olsa da bazı yönleriyle Memlükler dönemi öncü tarihçileri ve Halep tarihçilerinin eserlerinden ayrılmaktadır. Müellifinin kendi dönemine dair verdiği bilgilerin şahsî gözlemlerine dayanması hasebiyle bilhassa önemli olan bu eser, hem Memlükler dönemi Halep'inin siyasî, idarî, sosyal ve kültürel durumu hem de Ortaçağ tarih araştırmaları için kıymetlidir.

Anahtar Kelimeler: İslam Tarihi, Ortaçağ, Memlükler, Halep, Ebû Zer Sıbt İbnü’l-Acemî, Künûzü’z-Zeheb.

\section{An Example of Historiography in The Mamluk Period: Abu Zar Sibt Ibn al-Acami (ö. 884/1480) and His Book's Kunuz az-Zahab fi Tarikh Haleb}

Abstract Mamluk period is a period when scientific studies peaked. In addition to Cairo, the center of the state where these studies are more intense, important scientists have been trained in Damascus and Aleppo in the Syrian region. One of these is Abu Zar Sibt Ibn al-Acami al-Halebi. Abu Zar took lessons from many great scholars of his time and was among the prominent scholars during his lifetime. Although most of the works written by Abu Zar were lost, his work named Kunuz az-zahab fi tarikh Haleb has reached today, albeit partially. In this article, first of all, Abu Zar's life and works and then his work named Kunuz az-zahab are examined in terms of its history and content. Although the first volume is hetat, the second volume is predominantly events and deaths, it is possible to see all of the important elements such as nukât, avâil, al-'ajaib va'l-gharaib, which are important elements in Mamluk historiography, although it is taken as an example by previous historians in general terms. In some ways, it differs from the works of the Mamluk period pioneer historians and Aleppo historians. This work, which is especially important as the author's information about his period is based on his personal observations, is valuable both for the social and cultural situation of Aleppo during the Mamluk period and for medieval history studies.

Keywords: History of Islam, Medieval, Mamluks, Aleppo, Abu Zar Sibt Ibn al-Acami, Kunuz az-Zahab. 
Atmaca, Memlükler Dönemi Tarih Yazımına Bir Örnek: Ebû Zer Sibt İbnü’l-Acemî (ö. 884/1480) ve ...

\section{Giriş}

Asırlardır tarihin yazımı ve öğrenilmesine olan ilgi hiç azalmamıştır. Ancak bu ilginin zirve yaptığ dönemler olmuştur. İşte bu dönemlerden biri de hiç şüphesiz Memlükler dönemidir (648923/1250-1517). Bağdat'ın Moğol istilâsına maruz kaldığı ve bu nedenle Bağdat'taki Abbâsî Hilâfeti'nin (750-1258) son bulduğu sıralarda Mısır'daki Eyyûbî (567-650/1171-1252) hâkimiyetine son vererek devletlerini kuran Memlükler, başkent Kahire'ye diğer ülkelerden akın eden ulemâyı desteklemiş, bu sayede Memlük Devleti hızlı bir şekilde İslâm medeniyetinin ilim merkezi haline gelmiştir. Kahire'den sonra Dımaşk ve Halep de âlimlere ev sahipliği yapmıştır. Memlükler dönemi her alanda bugün halen başucu eseri olarak kullanılan kitapların telif edildiği bir dönemdir. İbn Teymiyye (ö. 728/1328), İbn Kesîr (ö. 774/1373), İbn Haldûn (ö. 808/1406), İbn Hacer (ö. 852/1449) gibi meşhur simalar bu dönemde yetişmiştir. Memlükler döneminde gelişen ilim dalları arasında tarihin yeri ise çok daha özeldir. Zira İslâm tarihinde ilk defa bir dönemde bu kadar çok sayıda tarih eseri kaleme alınmıştır. ${ }^{1}$

Özel olarak Memlükler dönemi tarihçiliğine dair ülkemizde yapılan ilk çalışma Samira Kortantamer'in makalesidir. ${ }^{2}$ Onun, Memlük tarihçiliğinde bir üslûp üzerine kaleme aldığı makale de bu anlamda önemlidir. ${ }^{3}$ Bunun dışında İsmail Yiğit, ${ }^{4}$ Altan Çetin, ${ }^{5}$ Cengiz Tomar ${ }^{6}$ gibi tarihçilerin bu alana katkı sunan çok değerli çalışmaları bulunmaktadır. Kortantamer'den sonra Memlük tarihçiliği hakkında özel olarak araştırmalar yapan Fatih Yahya Ayaz'ın çalışmaları ise bilhassa zikredilmelidir. Ayaz'ın, Memlükler dönemi tarih, tabakât, vefeyât, terâcim gibi eserlerini genel olarak ele aldığı makalelerinin ${ }^{7}$ yanı sıra Aygül Düzenli ile birlikte hazırladıkları dönemin Hıristiyan

\footnotetext{
${ }^{1}$ Memlük tarihçiliği hakkında detaylı bilgi için bk. Samira Kortantamer, "Memlûk Tarihçiliğine Genel Bir Bakış”, Tarih İncelemeleri Dergisi 1/1 (01 Haziran 1983), 31-35; Fatih Yahya Ayaz, Memlükler'de Tarih ve Tarihçiler (Ankara: Türk Tarih Kurumu, 2020).

${ }^{2}$ Kortantamer, "Memlûk Tarihçiliğine Genel Bir Bakış".

${ }^{3}$ Samira Kortantamer, "Memlûk Tarihçiliğinde Bir Üslup Unsuru el-'Acâib vel-Garâib”, Tarih İncelemeleri Dergisi 9/1 (01 Haziran 1994), 69-87.

${ }^{4}$ İsmail Yiğit, “Memlukler Dönemi (1250-1517) İlmî Hareketine Genel Bir Bakış”, Türkler Ansiklopedisi 5/ (2002), 748-756; İsmail Yiğit, Memlükler (İstanbul: Kayıhan Yayınları, 2008).

${ }^{5}$ Altan Çetin, "Memlûkler Devleti Tarihi Kaynakları", Ortaçă̆ Türk Tarihi Ana Kaynakları, ed. Altan Çetin (İstanbul, 2014), 117-141.

${ }^{6}$ Cengiz Tomar, “Tarih (Misır, Suriye ve Filistin)”, Türkiye Diyanet Vakfi İslâm Ansiklopedisi (İstanbul: TDV Yayınları, 2011).

${ }^{7}$ Fatih Yahya Ayaz, "Memlükler Döneminin (648-923/1250-1517) Öne Çıkan Vefeyât, Tabakât ve Terâcim Eserleri”, Çukurova Üniversitesi İlahiyat Fakültesi Dergisi 16/2 (2016), 1-38; A. mlf., "Memlükler Dönemi (648923/1250-1517) Tarih ve Tabakât Eserlerine Dair”, İslâm Tetkikleri Dergisi 10/1 (2020), 147-179.
} 
Atmaca, An Example of Historiography in the Mamluk Period: Abu Zar Sibt Ibn al-Acami (ö. 884/1480) and ...

tarihçileri, ${ }^{8}$ Safedî özelinde siyer çalışmaları ${ }^{9}$ gibi özel konularda yaptığı araştırmalar ve yine bu konuyu bir bütün olarak işlediği kitab ${ }^{10}$ ülkemizde Memlük tarihi ve tarihçileri hakkında bilgi edinilebilecek ender çalışmalardandır.

Memlükler dönemi tarih eserleri deyince akla gelen ilk isim şüphesiz Makrîzî'dir (ö. 845/1442). O, Mısır tarih ekolünün kurucusu kabul edilir. Makrîzî ve onun gibi Mısır'da yaşayan tarihçiler dışında Dımaşk'ta veya Halep'te yaşayan, tarih alanında mühim eserler telif eden âlimler de vardır. Mesela meşhur İbn Kesîr (ö. 774/1373) Dımaşklı, İbnü'l-Verdî (ö. 749/1349) ve İbn Habîb el-Halebî (ö. 779/1377) ise Halepli tarihçilerdir. Memlükler döneminde kaleme alınan tarih eserleri muhteva açısından tarihçinin yaşadığı şehre göre değişiklik arz etmektedir. Devletin merkezi Mısır'da yaşayan tarihçiler havâdise ağırlı verirken Şamlı tarihçiler eserlerinde vefeyâta daha fazla yer vermişlerdir. ${ }^{11}$ Ebû Zer'den bir asır önce yaşamış olan Halepli tarihçi İbn Habîb el-Halebî ise eserlerinde vefeyât kısmı daha hacimli olmakla birlikte kronolojik olarak havâdis ve vefeyâtı ele almıştır. ${ }^{12}$ Halep'te yetişmiş tarihçilerden bir diğeri olan Ebû Zer Sıbt İbnü’l-Acemî'nin Künûzü̈'zzeheb fi târihi Haleb adlı eseri yalnızca kronolojik olarak havâdis ve vefeyâtı ele almamakta eserin ilk kısmı hıtat türünün güzel bir örneğini sunmaktadır. Dolayısıyla Ebû Zer'in eseri, Memlükler ve komşu devletler hakkında naklettiği ve bizzat müşahede ettiği olayları aktarması, Halep hakkında oldukça detaylı bilgiler vermesi ve İbn Şeddâd'dan (ö. 684/1285) sonra Halep'teki mekânları her yönüyle ele alması nedeniyle değerli bir çalışmadır. Anlaşılır bir dilinin olması da eserden istifadeyi kolaylaştırmaktadır.

Memlükler dönemi tarih yazımında Arap tarihçiliğinde çok nadir görülen nukât, nevâdir ve el'acâib ve'l-garâib unsuru oldukça önemli bir yere sahiptir. Bu dönemde çok geniş bir okuyucu kitlesi vardı ve dolayısıyla çok sayıda tarih eseri kaleme alınıyordu. Bu eserlerin daha fazla kişi tarafından tercih edilmesi için de okuyucunun beklentilerini karşılaması gerekiyordu. Neticede tarihî bilginin yanında okuyanların ilgisini çekecek söz konusu unsurlar bu dönemin tarih kitaplarının belirgin özellikleri haline gelmişlerdir. Bu yönüyle Memlük tarih eserleri günümüz gazetelerine

\footnotetext{
${ }^{8}$ Aygül Düzenli - Fatih Yahya Ayaz, “Memlükler Dönemi Hıristiyan Tarihçileri”, Çukurova Üniversitesi İlahiyat Fakültesi Dergisi 17/2 (2017), 85-102.

${ }^{9}$ Fatih Yahya Ayaz, “Memlükler Döneminde (648-923/1250-1517) Siyer Çalışmaları Safedî’nin (ö. 764/1363) elVâfî Adlı Eserinde Hz. Peygamber’in Hayatı”, Siyer Araştırmaları Dergisi 4 (2018), 11-34.

${ }^{10}$ Ayaz, Memlükler'de Tarih ve Tarihçiler.

${ }^{11}$ Ayaz, Memlükler'de Tarih ve Tarihçiler, 206-207.

${ }^{12}$ Ebû Muhammed Bedrüddîn el-Hasen b. Ömer b. el-Hasen ed-Dımaşkî el-Halebî İbn Habîb, Tezkiretü’n-nebîh fî eyyâmi'l-Mansûr ve benîh, thk. Muhammed Muhammed Emîn (Kahire: el-Hey'etü'l-Misriyyetü'l-'Âmme li'lKitâb, 1986); Ebû Muhammed Bedrüddîn el-Hasen b. Ömer b. el-Hasen ed-Dımaşkî el-Halebî İbn Habîb, Dürretü'l-eslâk fî devleti'l-Etrâk (Kahire: Dâru'l-Kütüb ve'l-Vesâiki'l-Kavmiyye, 2014); Ayaz, Memlükler'de Tarih ve Tarihçiler, 206-207.
} 
Atmaca, Memlükler Dönemi Tarih Yazımına Bir Örnek: Ebû Zer Sibt İbnü’l-Acemî (ö. 884/1480) ve ...

benzetilmiştir. Çünkü Memlük toplumu bir tarih kitabı okurken hem haber edinmek, hem de eğlenmek istemiştir. Sonuç itibarıyla onların bu talepleri Memlükler dönemi tarih eserlerinde kendini göstermiştir. Tarih kitaplarındaki el-'acâib ve'l-garâibler genel hatlarıyla doğadaki, insanlar ve hayvanlardaki garip hadiseler, gaybî bilgi, ilginç karşılaştırma ve tesadüfler, bazı harf ve sayıların anlamları, kaderin cilvesi gibi konulardır. ${ }^{13}$ Bu makalede Ebû Zer'in eseri bu yönüyle de incelenmektedir.

Bu makalede öncelikle Ebû Zer Sıbt İbnü'l-Acemî el-Halebî̀nin hayatı ve eserleri ele alınmış, daha sonra Künûzü̈z-zeheb fî târîhi Haleb adlı kitabı detaylı bir incelemeye tabi tutulmuştur. Bu aşamada önce eserin genel özellikleri ortaya konulmuş, sonra da muhtevası uygun başlıklar altında incelenmiştir. Bu çalışmanın amacı Memlük Devleti'nin son asrında kaleme alınan bir tarih eserinin özelliklerini ortaya koymak ve bu dönemle ilgili çalışacak araştırmacılara ele alınan eserin sunacağı katkı konusunda bir fikir vermektir.

\section{Ebû Zer Sıbt İbnü’l-Acemî el-Halebî̀nin Hayatı ve Eserleri}

\subsection{Hayat1}

Tam adı Ahmed b. İbrahim b. Muhammed b. Halîl et-Trablusî el-Halebî eş-Şâfiî olup "Sıbt İbnü’lAcemî" diye meşhur olan Ebû Zer, 9 Safer 818 (20 Nisan 1415) tarihinde Halep'te dünyaya gelmiş, ${ }^{14}$ hayatının büyük çoğunluğunu burada geçirmiştir. Kendisinden önce babası Ebü'l-Vefâ (ö. 841/1438), ${ }^{15}$ anne tarafından dedesi Ömer b. Muvaffak İbnü'l-Acemîye nisbetle “Sıbt İbnü’l-Acemî” diye meşhur olmuştur. Ebû Zer, Memlükler dönemi boyunca ilimle meşgul olmuş ulemâ bir aileden gelmektedir. Geniş ailesi içerisinde ikisi kadın olmak üzere çoğunluğu hadis ile meşgul olmuş yirmi dokuz âlim tespit edilmiştir. Dedesi Ömer b. Muhammed'in çocuk ve torunları bunlar arasında çoğunluğu teşkil etmektedir. ${ }^{16}$ Hac için yola çıktığında $\left(837 / 1434{ }^{17}\right)$ bir süre Dımaşk'ta bulunmuştur. Babasından, asrının hocalarından dersler almış, fikıh, hadis, tarih, edebiyat gibi ilimlerle meşgul olmuş, manzum ve mensur birçok eser telif etmiştir. O, Halepli ulemâ dışında İbn Hacer gibi Halep'e gelen ve Dımaşk'tayken görüştüğü hocalardan da ders almıştır. Ebû Zer, babasından sonra en önemli

\footnotetext{
${ }^{13}$ Kortantamer, "el-‘Acâib ve'l-Garâib”, 70-71.

${ }^{14}$ Şemseddîn Muhammed b. Abdurrahman Sehâvî, ed-Dav'ü'l-lâmi' li ehli'l-karni't-tâsi' (Beyrut: Dâru'l-Cîl, 1992), 1/198; Ebü'l-Fazl Celâlüddîn Abdurrahman b. Ebî Bekr Süyûtî, Nazmü'l-'ikyân fì a'yâni'l-a'yân (Beyrut: elMektebetü'l-i̇lmiyye, ts.), 30.

${ }^{15}$ Sehâvî, ed-Dav'ü'l-lâmi', 1/138; İbrahim Hatiboğlu, “Sıbt İbnü'l-Acemî”, Türkiye Diyanet Vakfi İslâm Ansiklopedisi (İstanbul: TDV Yayınları, 2009).

${ }^{16}$ Bu makalede İbnü'l-Acemî ailesinin tüm bireylerinin zikredilmesi maksadı aşacağından detaylı bilgi için bk. Esra Atmaca, Halep’te İlmî Hayat Memlûkler Döneminde (1250-1517) (İstanbul: Ensar Neşriyat, 2016), 215-221.

${ }^{17}$ Sibt İbnü'l-Acemî Muvaffakuddîn Ahmed b. İbrahim Ebû Zer, Künûzü'z-zeheb fî târîhi Haleb, thk. Şevki Şa's Fâlih Bekkûr (Haleb: Dâru'l-Kalemi'l-'Arabî, 1996), 2/172.
} 
Atmaca, An Example of Historiography in the Mamluk Period: Abu Zar Sibt Ibn al-Acami (ö. 884/1480) and ...

hocası olan İbn Hatîb en-Nâsıriyye'nin (ö. 843/1440) ${ }^{18}$ kendisi için baba gibi olduğunu söylemektedir. ${ }^{19}$

Ebû Zer, ilk eğitimini babası Sıbt İbnü'l-Acemî'den (ö. 841/1438) almış, ${ }^{20}$ İbn Hatîb en-Nâsıriyye (ö. 843/1440), Şemseddîn es-Selâmî (ö. 879/1474), ${ }^{21}$ Alâüddin İbn Mektum er-Rahbî̀ den (ö. 848/1444$45)^{22}$ fıkıh; İbnü'l-A‘zâzî (ö. 876/1471), ${ }^{23}$ Şemseddîn es-Selâmî (ö. 879/1474), ${ }^{24}$ Şemseddîn el-Malatî (ö. ?), Kemâleddin Muhammed b. Nâsih'den (ö.?) ${ }^{25}$ Arapça; Sadaka'dan (ö.886/1481[?]) arûz öğrenmiş; ${ }^{26}$ Necmeddîn İbn Fehd'den (ö. 885/1480), Halep'e geldiğinde İbn Hacer el-Askalânî’den (ö. 852/1449), ${ }^{27}$ hac yolculuğu sırasında Dimaşk'tayken Âişe bint İbnü'ş-Şerâihî (ö. 842(1438), ${ }^{28}$ Abdurrahman Yusuf b. Tahhân (ö.?), ${ }^{29}$ Hafız İbn Nâsıruddîn (ö. 842/1438-39), ${ }^{30}$ İbn Fahruddin elMisrî̀den (ö. 867/1463) ${ }^{31}$ hadis dinlemiş; Zeynüddîn el-Harzî (ö. 862/1458), ${ }^{32}$ İbn Sehlûl (ö. 852/1449), ${ }^{33}$ Kemâleddin Muhammed b. Nâsih (ö.?), ${ }^{34}$ Muhammed el-Kütübî̀den (ö. 852/1449) de

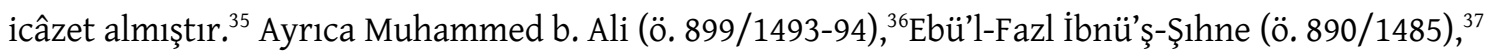
Dımaşk’taki Ali İbnü’s-Sayrafî (ö. 844/1440-41), ${ }^{38}$ Sirâcüddîn Ömer el-Hımsî el-Mahzûmî (ö. 861/1456-57), ${ }^{39}$ Şihâbüddîn Ahmed b. Ebî Bekr el-Hamevî (ö. 844/1440-41), ${ }^{40}$ Sirâcüddîn Abdüllatif b.

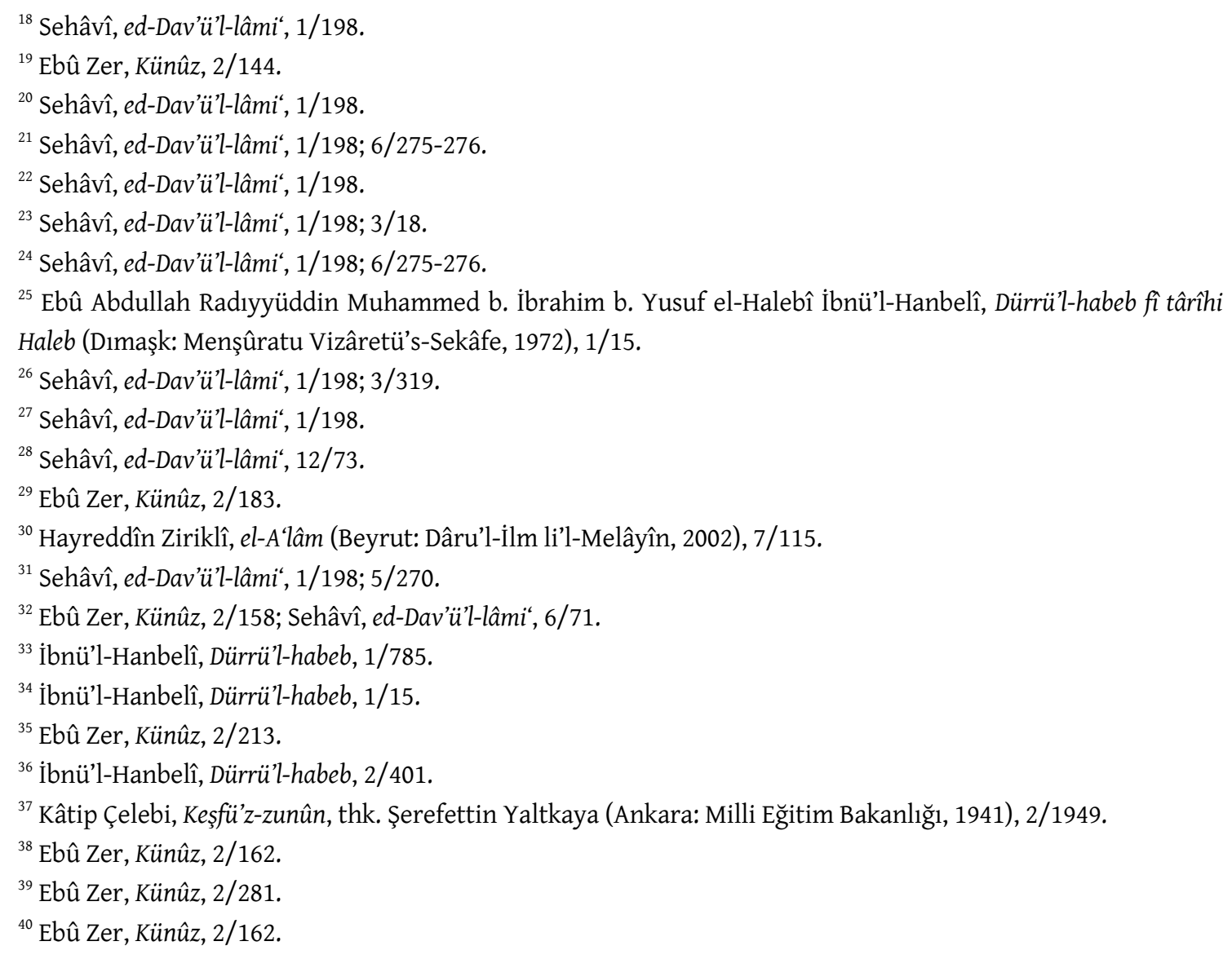


Atmaca, Memlükler Dönemi Tarih Yazımına Bir Örnek: Ebû Zer Sibt İbnü’l-Acemî (ö. 884/1480) ve ...

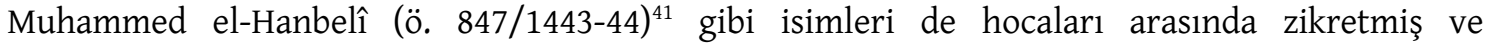
Abdurrahman b. Ebî Bekr eş-Şâmî’den (ö. 856/1452) At ânî Zâviyesi'nde hırka giymiştir. ${ }^{42}$

Ebû Zer'den hadis dinleyen, ders ve icazet alan talebeleri arasında Kādılkudât İbnü’s-Seyyid (ö. 895/1489'dan sonra), Halep Camii vâizi Şihâbüddîn Ahmed el-Hâdırî (ö. 923/1517-18), İbnü’s-Süyûfî (ö. 925/1519), Yeşbekiyye Fakîhi İbrahim b. Ahmed el-Kürdî (ö. 933/1526-27), Mahmud b. Ahmed elKureşî (ö. 934/1527-28) gibi isimler vardır. ${ }^{43}$

Ebû Zer, 882 (1477-78) yılında bir hastalık geçirmiş ve bu hastalığından iyileşmesine rağmen hafızasında zayıflık ve görme kaybı yaşamıştır. 884 (1479-80) yılına kadar bu sıkıntısı devam etmiş, sonra bu yıl gözleri yeniden görmeye başlamıştır. Ancak bu iyi hali çok sürmemiş ${ }^{44}$ ve aynı yıl yani 884'te (1480) Halep'te vefat etmiştir. ${ }^{45}$ Sehâvî, biyografisini verdiği Ebû Zer'i övmüş, onun saygıdeğer, mütevâzi, zâhid biri olduğunu ve ondan sonra onun gibi birinin olmadığını söylemiştir. ${ }^{46}$

Ebû Zer vefat ettikten sonra babasının da medfûn bulunduğu kabristana defnedilmiştir. Künûzü'z-Zeheb'i neşredenlerin aktardığına göre Halep'te Ebû Zer Camii diye bilinen bir yerin güneydoğusunda içerisinde sekiz mezarın olduğu bir mezarlık vardır. Mezarlıkta herhangi bir kitâbe vs. olmadığı için bunların Ebû Zer ve ailesine ait olduğu tahmin edilmekteydi. Sonra Ahmed Serdar adlı araştırmacı bu mekâna farklı bir yönden bakmış, medfûn olanların isimlerinin yazılı olduğu bir kitâbe bulmuştur. Aralarında Allâme Müerrih Muvaffakuddîn Ebû Zer Ahmed b. Burhânüddîn İbrahim b. Muhammed b. Halil Sıbt İbnü'l-Acemî el-Halebî eş-Şâfiî ismi de vardır. ${ }^{47}$ Neticede bu mezarlığın Ebû Zer ve ailesine ait olduğu tahmini doğru çıkmıştır. Bu kitâbede müellifin sadece tarihçiliğine atıf yapılması dikkat çekicidir. Zira onun fikıh, hadis ve edebiyat alanında daha fazla çalıştığı ifade edilmektedir. ${ }^{48}$

\section{2. Eserleri}

Ebû Zer Sıbt İbnü'l-Acemî'nin nazım ve nesir türünde yazılmış eserlerinin sayısı çok olmakla birlikte bunların büyük bir kısmı kayıptır. Bilinen eserleri şunlardır:

\footnotetext{
${ }^{41}$ Ebû Zer, Künûz, 1/30. (Neşredenin girişi)

${ }^{42}$ Sehâvî, ed-Dav'ü'l-lâmi', 1/198; 4/62-63.

${ }^{43}$ Ebû Zer, Künûz, 1/30-32. (Neşredenin girişi)

${ }^{44}$ Sehâvî, ed-Dav'ü'l-lâmi', 1/200.

${ }^{45}$ Sehâvî, ed-Dav'ü'l-lâmi', 1/200; Ebü'l-Felâh Abdülhay b. Ahmed b. Muhammed es-Sâlihî İbnü'l-İmâd, Șezerâtü'zzeheb fî ahbâri men zeheb, thk. Abdülkadir Arnâût - Mahmûd Arnâût (Beyrut: Dâru İbn Kesîr, 1986), 9/508.

${ }^{46}$ Sehâvî, ed-Dav'ü'l-lâmi', 1/200.

${ }^{47}$ Ebû Zer, Künûz, 1/39. (Neşredenin girişi)

${ }^{48}$ Sehâvî, ed-Dav'ü'l-lâmi', 1/199-200; Ali Öngül, "Ebû Zer el-Halebî”, Türkiye Diyanet Vakfi İslâm Ansiklopedisi (İstanbul: TDV Yayınları, 1994).
} 
Atmaca, An Example of Historiography in the Mamluk Period: Abu Zar Sibt Ibn al-Acami (ö. 884/1480) and ...

a. Evfe'l-vâfiye fî șerhi'l-kâfiye: İbnü'l-Hâcib'in (ö. 646/1249) Arap nahvine dair muhtasar eseri üzerine yazılmıştır. ${ }^{49}$

b. et-Tavdîh li'l-evhâmi'l-vâkl'atü fi's-Sahîh : Buhârî șerhidir. ${ }^{50}$

c. Mübhemâtü'l-Buhârî: İbnü'l-Irakî’nin (ö. 826/1423) mübhemâta dair eseri üzerine yazılmıştır. ${ }^{51}$

d. Şerhu'ş-Şifâ: Kâdî İyâz'ın (ö. 544/1149) eserinin şerhidir ve tamamlayamamıştır. ${ }^{52}$

e. el-Mesâbîh: Ferrâ el-Begavînin (ö. 516/1122) Mesâbihü's-Sünne adlı hadis eserinin şerhi olup tamamlayamamıştır. ${ }^{53}$

f. Sitrü'l-hâl fimâ kîl fi'l-hâl ${ }^{54}$

g. Seyrü'l-cemâl fîmâ yükâl fi'l-hâl: Ömrünün sonlarında kaleme almıştır. ${ }^{55}$

h. 'Arûsü'l-efrâh fî mâ yükâl fi'r-râh ${ }^{56}$

1. 'íkdü'd-dürer ve'l-lâl fimâ yükâl fi's-selsel ${ }^{57}$

i. et-Tevki' bi bâbi İbn Hatîb en-Nâstriyye ${ }^{58}$

j. Kurretüll-'ayn fí fedâili'ş-şeyhayn ve's-sahrayn ve's-sibtayn ${ }^{59}$

k. Künûzü'z-zeheb fî târîhi Haleb ${ }^{60}$

1. Mübhemâtü Müslim ${ }^{61}$

\footnotetext{
${ }^{49}$ Bağdatlı İsmail Paşa, Hediyyetül'-ârifin esmâi'l-müellifin ve âsâru'l-musannifin (Beyrut: Dâru İhyâi't-Türasi'l'Arabî, 1951), 1/134.

${ }^{50}$ Sehâvî, ed-Dav'ü'l-lâmi', 1/199; Kâtip Çelebi, Keşfü'z-zunûn, 1/553; Bağdatlı İsmail Paşa, Hediyyetü'l-ârifinn, $1 / 134$.

${ }^{51}$ Sehâvî, ed-Dav'ü'l-lâmi', 1/198; Kâtip Çelebi, Keşfü'z-zunûn, 2/1583-84; Bağdatlı İsmail Paşa, Hediyyetü'l-ârifîn, $1 / 134$.

${ }^{52}$ Sehâvî, ed-Dav'ü'l-lâmi', 1/199; Kâtip Çelebi, Keşfü'z-zunûn, 2/1054.

${ }^{53}$ Sehâvî, ed-Dav'ü'lllâmi', 1/199.

${ }^{54}$ Sehâvî, ed-Dav'ü'llâmi', 1/198.

${ }^{55}$ Bağdatlı İsmail Paşa, Hediyyetül'-ấrifin, 1/134; Kâtip Çelebi, Keş̧ü'z-zunûn, 2/1012. Bu eser bir önceki eserle aynı olup adı farklı kaydedilmiş olabilir.

${ }^{56}$ Sehâvî, ed-Dav'ü'l-lâmi', 1/198; Kâtip Çelebi, Keş̧ü'z-zunûn, 2/1133; Bağdatlı İsmail Paşa, Hediyyetü'l-'ârifin, $1 / 134$.

${ }^{57}$ Sehâvî, ed-Dav'ü'l-lâmi', 1/198; Kâtip Çelebi, Keş̧ü'z-zunûn, 2/1151; Bağdatlı İsmail Paşa, Hediyyetü'l-ârifîn, $1 / 134$.

${ }^{58}$ Sehâvî, ed-Dav'ü'l-lâmi', 1/198.

${ }^{59}$ Sehâvî, ed-Dav'ü'l-lâmi', 1/199; Kâtip Çelebi, Keş̧ü'z-zunûn, 2/1325; Bağdatlı İsmail Paşa, Hediyyetü'l-ârifîn, $1 / 134$.

${ }^{60}$ Bağdatlı İsmail Paşa, Hediyyetül-ấrifin, 1/134.

${ }^{61}$ Sehâvî, ed-Dav'ü'l-lâmi', 1/199; Kâtip Çelebi, Keşfü'z-zunûn, 2/1584.
} 

m. el-Hilâlü'l-müstenîr fi'l-fedâi'l-müstedîr ${ }^{62}$
n. el-Hilâlü'l-müstenîr fi'l-'izâri'l-müstedîr ${ }^{63}$
o. el-Bedru izâ istinâru fimâ kîl fil'-'izâr ${ }^{64}$
ö. el-Kevâkibi'l-mudîe $e^{65}$

\section{Künûzü'z-zeheb fi târîhi Haleb Adlı Eseri}

Ebû Zer'in eseri Künûzü'z-zeheb fî târîhi Haleb (Halep tarihi hakkında altından hazineler), İbnü'lAdîm'in (ö. 660/1262) Buğyetü't-taleb fî târihi Haleb ${ }^{66}$ adlı eserine Ebû Zer'in hocası İbn Hatîb enNâsıriyye'nin zeyl olarak yazdığı Dürrü'l-müntehâb fi târihi Haleb'e ${ }^{67}$ zeyl olarak yazılmıștır. Künûz'a da daha sonra İbnü'l-Hanbelî (ö. 971/1563) Dürrül-habeb fi târihi a'yâni Haleb ${ }^{68}$ adlı bir zeyl yazmıştır. ${ }^{69}$

Neşredenlerin aktardığına göre Künûzü'z-zeheb' in yalnızca iki nüshası günümüze ulaşmıştır. $\mathrm{Bu}$ nüshalarda ise eksiklikler ve yazma kusurları bulunmaktadır. Vatikan Kütüphanesi'nde bulunan nüshanın başı ve sonu eksiktir. 119 varaktan oluşan nüshanın 27. varakasında bulunan bir nottan dolayı 1170 yılından sonra yazıldığı tahmin edilmektedir. Bu nüsha müellifin müsveddeleriyle başlamaktadır. Çünkü bu sayfalarda muhtemelen müellifin daha sonra tamamlamak üzere boş bıraktığı yerler bulunmaktadır. Mısır Dâru'l-Kütüb'teki nüshada ise takdim, tehir, tekrar gibi problemler vardır. Bu nüshanın hıtat türündeki birinci cildi 221 sayfa, havâdis türündeki ikinci cildi ise 110 sayfadır. Bu eseri neşredenler Şevkî Şa's ve Fâlih Bekkûr'dur. Neşredenlerin ilaveleriyle birlikte birinci cildi 625, ikinci cildi 496 sayfa olarak yayımlanmıştır. Birinci cilt ilk kısımları eksik olduğu için beşinci bölümle başlamış, müellifin daha sonra ikmal etmek için boş bıraktığı yerlerin bazıları sonradan tamamlanmış, bazıları ise boş kalmıştır. Nâş̧irler, eseri aslına en uygun şekliyle yayımlamaya gayret ettiklerini belirtmişlerdir. ${ }^{70}$ Eserin sonunda Halepli tarihçi Kâmil el-Gazzînnin (ö. 1933) Künûzü'-z-zeheb'in müsveddelerinden elde ettiğini iddia ettiği şiirler bulunmaktadır. Bu

\footnotetext{
${ }^{62}$ Bağdatlı İsmail Paşa, Hediyyetü'l-'ârifîn, 1/134.

${ }^{63}$ Sehâvî, ed-Dav'ü'l-lâmi', 1/198.

${ }^{64}$ Sehâvî, ed-Dav'ü'l-lâmi', 1/198.

${ }^{65}$ Ebû Zer, Künûz, 1/14. (Neşredenin girişi)

${ }^{66}$ İbnü'l-Adîm'in bu eserinin bugün mevcut olan kısmı 10 cilttir. Neşirlerinde bu 12 cilde çıkmaktadır. Ebü'lKâsım Kemâleddîn Ömer b. Ahmed İbnü'l-Adîm, Buğyetü't-taleb fî târîhi Haleb (Beyrut: Dâru'l-Fikr, ts.).

${ }^{67}$ İbn Hatîb en-Nâsıriyye bu eserde a'yânı alfabetik olarak tertip etmiştir. Kâtip Çelebi, Keşfü'z-zunûn, 1: 249. Bu eserin yanlışlıkla Ebü'l-Fazl İbnü'ş-Şıhne'ye nispet edilen eser olduğu ifade edilmektedir. Ebü'l-Fazl Muhibbüddîn Muhammed b. Muhammed İbnü'ş-Şıhne, ed-Dürrü'l-müntehâb fî târîhi memleketi Haleb (Dımaşk: Dâru'l-Kitâbi'l-'Arabî, 1984).

${ }^{68}$ İbnü'l-Hanbelî, Dürrü’l-habeb; Kâtip Çelebi, Keşfü’z-zunûn, 1/249; Ali Sevim, “Buğyetü’t-taleb”, Türkiye Diyanet Vakfi İslâm Ansiklopedisi (İstanbul: TDV Yayınları, 1992).

${ }^{69}$ Kâtip Çelebi, Keşfü'z-zunûn, 1/249, 292; 2/1520.

${ }^{70}$ Ebû Zer, Künûz, 1/5-6, 40-46. (Neşredenin Girişi)
} 
Atmaca, An Example of Historiography in the Mamluk Period: Abu Zar Sibt Ibn al-Acami (ö. 884/1480) and ...

şiirler Arap, Acem, Türk, Deylem, Kürt gibi milletler ve Hemedân, Basra, Bağdat, Halep, Hama, Hicaz gibi şehirler hakkında kaleme alınmışlardır. ${ }^{71}$ Ebû Zer'in edebiyatla yakından ilgili olduğu, nazım türünde eserler verdiği ve Künûz'da da buna dair pek çok örnek bulunduğuna göre bu şiirlerin ona ait olması mümkündür. Neşredenler tarafından, Künûz'da adı geçen kaynaklar özel bir fihristte alfabetik olarak listelenmiştir. Buna göre Künûz'da 118 eserin adı geçmektedir. ${ }^{72}$ Bu, müellifin çok zengin bir kaynak grubundan istifade ettiğini göstermektedir.

Künûzü'z-zeheb'in ilk cildi genel olarak hitat, ikinci cildi ise havâdis ve vefeyâta dairdir. Memlükler dönemi tarih yazımına mahsus özelikler, bu eserde görülmektedir. Nitekim Memlük tarihçiliğinde gerek dil gerekse üslup bakımından bazı farklar göze çarpmaktadır. Bu dönemin tarih eserleri bugünkü gazetelerin fonksiyonunu üstlenmiş, döneminin insanları tarafindan ilgiyle okunmuştur. Bu amaçla eserlere dikkat çekici anekdot vb. unsurlar eklenmiştir. Bu unsurlardan biri de el-'acâib ve'l-garâibdir. ${ }^{73}$ Ebû Zer, bu eserinde el-'acâib ve'lgarâibe özel bir yer ayırmış olmasına rağmen sene be sene bilgi verdiği kısımda da bu kapsamda değerlendirilebilecek konulara değinmiştir. ${ }^{74}$ Daha önceki tarih eserlerinde bulunsa da Memlük tarih eserlerinde belirgin bir artış görülen "nukât"lar da bu eserde oldukça fazladır. Nukât, yani adekdotlar tarihî olaylar arasına serpiştirilmiş dikkat çekici bilgilerdir. ${ }^{75}$ Ebû Zer, eserinde "latîfe", "hikâye" başlıkları altında dikkat çekici bazı bilgiler vermiştir. Buna örnek olarak Süleyman b. Abdülmelik'in (ö. 99/717) kabrinin açılmasından bahsettikten sonra latife başlığı altında onun yemek yemeyi seven biri olduğuna, oğullarının ona engel olmak istediğine dair bilgiler verilebilir. ${ }^{76}$ Bazen de "'fâide" başlığıyla ilave bilgilere yer vermiştir. Ebû Zer, kendisinin de hayatta olduğu 825 (1421-22) vebasına dair bilgi verdikten sonra "fâide" başlığıyla İslam dünyasında beş büyük tâun olduğunu yazıp açıklama yapmaktadır. ${ }^{77}$ Bundan sonra da "diğer fâide” başlığı ile İbn Kuteybe'nin (ö. 276/889) Mekke ve Medine'de asla tâun olmayacağına dair sözünü aktarmaktadır. ${ }^{78}$

\footnotetext{
${ }^{71}$ Ebû Zer, Künûz, 2/345.

${ }^{72}$ Ebû Zer, Künûz, 2/463-466.

${ }^{73}$ Konu hakkında detaylı bilgi için bk. Kortantamer, "el-'Acâib ve'l-Garâib”.

${ }^{74}$ Ebû Zer, Künûz, 2/210.

${ }^{75}$ Kortantamer, "Memlûk Tarihçiliğine Genel Bir Bakış", 33.

${ }^{76}$ Ebû Zer, Künûz, 1/120-121.

${ }^{77}$ Ebû Zer, Künûz, 1/170.

${ }^{78}$ Ebû Muhammed Abdullah b. Müslim ed-Dîneverî İbn Kuteybe, el-Ma ârif, thk. Servet Ukkâşe (Kahire: Dâru'lMe'ârif, 1992), 602; Ebû Zer, Künûz, 1/170.
} 


\section{Künûzü'z-zeheb'in Muhtevâsı}

\subsection{Birinci Cilt / Hitat}

Bir şehrin topoğrafyası, tarihî coğrafyası, ekonomik ve kültürel durumu, mahalleleri, bina ve tesisleri hakkında bilgi veren Arapça eserlerin ortak adı olarak tanımlanan hıtat türü, şehir tarihleri ve tarihî-coğrafya kitaplarında ayrı bir bölüm halinde, diğer tarih eserlerinde yeri geldikçe ele alınırken müstakil olarak bu amaçla kaleme alınan eserler de vardır. Memlükler döneminde hıtat türü Mısırlı ulemânın ilgi gösterdiği bir edebî tür haline gelmiş ve Makrîzî bu türü zirveye ulaştırmıştır. ${ }^{79}$ Makrîzînin el-Mevâ'iz ve'l-i'tibâr bi zikri'l-hitât ve'l-âsâr adında olup Hitatü'l-Makrîziyye diye meşhur olan eseri hem bu türün en ünlüsü olmuş hem de kendinden sonra yazılan bu alandaki eserlere kaynaklık etmiştir. ${ }^{80}$

Ebû Zer'in Künûz'unun ilk cildi hıtat ağırlıklıdır. Birinci cildin ilk dört bölümü kayıp olduğu için beşinci bölümden başlamaktadır. Buna göre beşinci bölümde aşka dair konular, altıncı bölümde detaylı bir şekilde yerleriyle birlikte tılsımlı olduğuna inanılan yapı, mekân ve eşyalar, yedinci bölümde Halep ve çevresinde defnedilmiş olan halifeler ve sultanlar, sekizinci bölümde Halep'te görülen acâib olaylar, dokuzuncu bölümde Haçlılar'la yaşanan bazı olaylar, onuncu bölümden itibaren de şehrin yapısı ve mekânları ele alınmıştır. Müellifin bu ciltte ilk bölümler hariç Makrîzînin Hıtât'ını örnek aldığı görülmektedir. ${ }^{81}$ Ebû Zer'in aşk konusunu özel bir bölüm yapması edebiyata olan ilgisinden olmalıdır. Bu bölümde aşkından ölenlerin şehit olup olmadığına dair görüşlere değindikten sonra aşkı nedeniyle sıkıntı çeken kişilerden olaylar anlatmaktadır. Bu bölüm oldukça hacimli, yirmi sayfadan fazladır. Olaylar arasında aşka dair, aşkın ihtiyârî mi ıztırârî mi olduğu gibi tartışmalara ve görüşlere yer vermektedir. ${ }^{82}$

Haçlılar'la ilgili bölüm kronolojiktir. 245-516 (859-1123) yılları arasını kapsayan bu olayları Halep ve civarı merkezli olarak kaydetmiştir. İbnü'l-Esîr (ö. 630/1233) ve Ebü'l-Fidâ’nın (ö. 732/1331) eserleri bu bölümün önde gelen kaynaklarıdır. ${ }^{83}$

Ebû Zer, cami, medrese, ribat, zaviye gibi yapıları tanıttığı bölümde önce Halep’te yapılan ilk mescid hakkında bilgi vermiş, ${ }^{84}$ ardından İbn Şeddâd zamanında Cuma namazı kılınan camileri, daha

\footnotetext{
${ }^{79}$ İsmail Yiğit, “Hitat”, Türkiye Diyanet Vakfi İslâm Ansiklopedisi (İstanbul: TDV Yayınları, 1998), 17/401.

${ }^{80}$ Mehmet İpşirli, “Hıtatü'l-Makrîziyye”, Türkiye Diyanet Vakfi İslâm Ansiklopedisi (İstanbul: TDV Yayınları, 1998), $17 / 402$.

${ }^{81}$ Ebü'l-Abbas Takıyyüddin Ahmed b Ali b Abdülkadir Makrîzî, el-Mevâ'iz ve'l-i'tibâr bi zikri'l-hıtat ve'l-âsâr, thk. Muhammed Zeynühüm - Medîha Şerkâvî (Kahire: Mektebetü Medbûlâ, 1998).

${ }^{82}$ Ebû Zer, Künûz, 1/53 vd.

${ }^{83}$ Ebû Zer, Künûz, 1/178-204.

${ }^{84}$ Ebû Zer, Künûz, 1/206.
} 
sonra İbn Şeddâd'dan sonra yenilenen camileri anlatmıştır. Bunların sayısı otuz sekizdir. Makalenin sınırlarını aştığı için isimleri metinden çıarılmıştır. ${ }^{85}$ Camileri tanıtırken bunların inşası hakkında sık sık şiirlere yer vermektedir. Bu bilgiler arasında da latîfeler, garâibler yer almıştır. ${ }^{86}$ Bunlar arasında camiye namaza giderken yeni ayakkabılar giyen bir kişi ve o ayakkabıların başına gelenler bile bulunmaktadır. ${ }^{87}$

Şehrin medreselerini mezheplere göre sınıflandırarak tanıtmadan önce mescid yapmanın fazileti, buna dair hadisler ve İslam'daki ilk medrese hakkında bilgiler vermiş sonra da yirmi beş adet Şâfiî, ${ }^{88}$ yirmi altı adet de Hanefî medresesini tanıtmıştır. ${ }^{89}$ Mâlikî ve Hanbelî medreseleri olarak da Emir Seyfeddin Ali b. Süleyman'ın inşa ettiği bir medreseden ve Câmiu'l-Kebîr'deki zaviyeden bahsetmektedir. ${ }^{90} \mathrm{Bu}$ medreselerin sadece mimarî özelliklerini vermemiş, bânilerinin hayatları, medresede okutulan dersler, vakfiyelerinde belirtilen şartlar, görev yapan müderrislere dair de kıymetli bilgiler sunmuştur. Mesela Asrûniyye Medresesi hakkında önce bânîsi Sultan Nureddin Mahmûd Zengî (ö. 569/1174) ve ilk müderrisi İbn Asrûn'u (ö. 585/1189), sonra da ayrı ayrı medresenin müderrislerini tanıtmıştır. Bu açıdan eser Halep ilmî hayatının öğrenilmesi için değerlidir. Onun bu konulara giriş yaparken hadislere yer vermesi muhaddis yönüyle de ilgilidir. Ebû Zer' in birçok hocadan hadis dinlediği ve bu alanda eserler kaleme aldığı daha önce zikredilmişti.

Medreselerden sonra dönemin ihtisas merkezleri olarak düşünülebilecek olan dâru'l-Kur'an ve dâru'l-hadislere, ${ }^{91}$ genellikle bir medresenin bünyesinde faaliyet gösteren on beş yetim mektebine, ${ }^{92}$ hankah (Halep'in içinde yirmi altı, dışında beş tane), ${ }^{93}$ ribat ve tekke (üç tane) ${ }^{94}$ zâviye (on yedi $\operatorname{tane})^{95}$ gibi mekânlara yer vermektedir. Tanıttığı bu yapı türlerinin sonuncusu ise türbelerdir. Eserde çoğunluğu âlimlere ait olmak üzere yirmi dokuz türbeden, ${ }^{96}$ son olarak da dört

\footnotetext{
${ }^{85}$ Ebû Zer, Künûz, 2/213-267.

${ }^{86}$ Ebû Zer, Künûz, 1/228-229.

${ }^{87}$ Ebû Zer, Künûz, 1/228-229.

${ }^{88}$ Ebû Zer, Künûz, 1/270-329.

${ }^{89}$ Ebû Zer, Künûz, 1/339-270. Ebû Zer' in eserinde yer verdiği 55 medresenin 44 tanesi Memlük öncesi yani Zengî ve Eyyûbî dönemlerinde diğerleri ise Memlûkler döneminde inşa edilmişlerdir. Camilerdeki ders halkalarında da eğitim öğretim devam etmiştir. Halep'teki ilmî kurumlar için bk. Atmaca, Halep'te İlmî Hayat Memlûkler Döneminde (1250-1517).

${ }^{90}$ Ebû Zer, Künûz, 1/371.

${ }^{91}$ Ebû Zer, Künûz, 1/372-379.

${ }^{92}$ Ebû Zer, Künûz, 1/440-444.

${ }^{93}$ Ebû Zer, Künûz, 1/384-403.

${ }^{94}$ Ebû Zer, Künûz, 1/426.

${ }^{95}$ Ebû Zer, Künûz, 1/406-425.

${ }^{96}$ Ebû Zer, Künûz, 1/427-439.
} 
Atmaca, Memlükler Dönemi Tarih Yazımına Bir Örnek: Ebû Zer Sibt İbnü’l-Acemî (ö. 884/1480) ve ...

bîmâristandan ${ }^{97}$ bahsetmektedir. Ebû Zer, müesseseler konusunda kendisinden iki asır önce yaşamış olan İbn Şeddâd'dan nakiller yapmıştır. İbn Şeddâd'dan sonra Halep'teki bu mekânlar hakkında en kapsamlı eser Ebû Zer'in bu eseridir. ${ }^{98}$

Halep şehri hakkında verdiği bilgiler arasında sokaklar (65 adet), çarşılar (3 adet), kale, dâruladl, surlar, kapılar (15 adet), meydanlar (3 adet), nehir ${ }^{99}$ ve dağlar ${ }^{100}$ bulunmaktadır. Her ne kadar Ebû Zer bunları özel bir başlık altında anlatsa da havâdis bölümünde 853 (1449) yılında Halep surlarının ve bir köprünün yapım kararı ve işlemlerinden detaylıca bahsetmektedir. ${ }^{101}$ Dolayısıyla hıtat kısmına malzeme olabilecek bilgiler havâdisin bulunduğu ciltte de karşımıza çıkabilmektedir.

Ebû Zer, el-'acâib ve garâibe dair konuları III./IX. yüzyıldan kendi çağı olan IX./XV. yüzyıla kadar kronolojik olarak ele almaktadır. Bu sırada "latîfe" başlığıyla ilave olaylar aktarmaktadır. Bu bölümde yaratılış itibarıyla normal bir insandan farklı olarak dünyaya gelen, birden fazla kafası, yüzü olan veya yapışık olarak doğan ikizler çokça yer bulmaktadır. Mesela 352 (963-964) yılında yaşayan ve 25 yaşına kadar gelmiş olan yapışı ikizler bunlardan biridir. Bu ikizlerin ayakları ortaktı ve arkadan bakıldığında bir kişi oldukları zannedilmekteydi. Devlet adamlarından Nâsıruddevle (ö. 358/969) onları bir doktora göstermiş, doktor da onlara beraber mi yoksa ayrı ayrı mı acıkıp susadıklarını sormuştur. Bu sorular iç organların ortak olup olmadığını anlamak için olmalıdır. Bu sorulara evet cevabını alan doktor, ikizlerin ayrılmaları halinde ölebileceklerini söylemiştir. Babası onların bu şekilde yaşamalarının çok zor olduğunu, sürekli kavga ettiklerini, sonra da küsüp konuşmadıklarını söyleyip sonuca razı olacaklarını belirtince ikizler ayrılmış, ameliyattan sonra biri hayatını kaybetmiş fakat diğeri uzun süre yaşamaya devam etmiştir. ${ }^{102}$ Tarihte ilk siyam ikizi ayırma operasyonunun X. asırda İstanbul'da Bizanslı bir doktor tarafından gerçekleştirildiği belirtilmektedir. Bu operasyonda ikizlerden biri ameliyat sonrası ölürken diğeri de sadece üç gün yaşayabilmiştir. ${ }^{103}$ Aynı yüzyılda Bağdat'ta bu operasyonun yapılmış olması hem de ikizlerden birinin uzun süre yaşamını devam ettirebilmesi oldukça dikkat çekicidir. Bu gibi bilgiler İslam tıp tarihi çalışmaları için değerlidir.

\footnotetext{
${ }^{97}$ İslâm tarihinde hastaneler için kullanılan bir kelimedir. Bu kelimelerin dışında İslâm dünyasında "dârü'ttıb”, “dârü’ş-şifâ”, “dârü’s-sıhha”, “dârü’l-merzâ”, "dârü'l-‘âfiye”, “mâristân”, "bîmârhâne” kelimeleri de hastaneler için kullanılmıştır. Ali Haydar Bayat, Tıp Tarihi (İstanbul: Merkezefendi Geleneksel Tıp Derneği, 2010), 207.

${ }^{98}$ Ebû Zer, Künûz, 1/206 vd.

${ }^{99}$ Ebû Zer, Künûz, 1/451-562.

${ }^{100}$ Ebû Zer, Künûz, 1/595-601.

${ }^{101}$ Ebû Zer, Künûz, 2/223.

${ }^{102}$ Ebû Zer, Künûz, 1/140.

${ }^{103}$ A. Erler vd., "Yapışık İkizler”, Perinatoloji Dergisi 4/2 (1996), 110-112.
} 
Atmaca, An Example of Historiography in the Mamluk Period: Abu Zar Sibt Ibn al-Acami (ö. 884/1480) and ...

Ebû Zer, yukarıdakine benzer bir başka tecrübeyi babasına ait bir kitaptan aktarmaktadır. Babası Yemen'e gittiğinde orada vücudunun yarısından aşağısı tek bir kadın bedeni, yukarısında ise iki ayrı beden olan siyam ikizlerini görmüştür. Ebû Zer bu ikizleri de uzun uzun anlatmıştır. ${ }^{104}$

Bir başka garip olay 647 (1249-50) yılında Bağdat'taki bir kadının tek batında 32 bebek doğurmasıdır. Bu kadının haberi halifeye ulaşınca kadın Dârulhilâfe'ye davet edilmiş ve kendisine bin dinarlık hediye takdim edilmiştir. Bu olayı aktardıktan hemen sonra kırk çocuk dünyaya getiren bir kadından (hatta bu kırk çocuğun büyüyüp babaları ile savaştıklarından) ve yine tek seferde beş bebek dünyaya getiren birinden daha bahsetmektedir. ${ }^{105}$ Aktarılan bu bilgilerden özellikle tek seferde 32 veya 40 çocuğun dünyaya gelmesi mantık sınırlarını aşan anlatılardır.

Doğumsal anomalilere dair Ebû Zer, 762'de (1360-61) Halep naibine gelen bir adamın iki başlı bir çocuğunun dünyaya geldiğini, sadece bir saat yaşadıktan sonra öldüğünüu, ${ }^{106} 810$ (1407-08) yılında ise babasının aktardığına göre Halep'te dünyaya gelen bir çocuğun tek kafada iki tane yüzü bulunduğunu, bunların birinin kafasının önünde diğerinin arkasında olduğunu anlatmaktadır. Bu bebek doğduktan kısa süre bir süre sonra ölmüştür. ${ }^{107}$ Bir başka garip doğum 852 (1448-49) yılında müellifin döneminde gerçekleşmiştir. Buna göre Sermîn ${ }^{108}$ beldelerinden birinde bir tek boyunda iki başı olan bir çocuk dünyaya gelmiştir. Bu başlarda bulunan her iki yüzünde de iki göz, dudak, burun bulunmaktaydı. Bu bebek, sadece bir gün yaşadıktan sonra hayatını kaybetmiştir. ${ }^{109} 835$ (1431-32) yılında Fâtıma bint Celâleddîn el-Bulkīnînnin çift cinsiyetli bir bebeği ölü doğurduğu veya doğduktan sonra öldüğ̈̈ü, ${ }^{110}$ (Safvân b. İsâ'dan naklen) Muhammed b. Aclân'ın annesinin karnında tam üç yıl kaldığı, doğum gerçekleşmeyince karnının yarılıp çıkarıldığı ve doğduğunda dişlerinin bulunduğu ${ }^{111}$ Ebû Zer'in anlattığı garip olaylar arasındadır.

Ebû Zer, garip doğan insan yavrularından başka diğer canlılar hakkında da benzer şeyler anlatmaktadır. Mesela 820 (1417) yılı Muharrem ayında iki başlı ve iki boyunlu, iki elli, iki ayağı tek bir yerden çıkan bir buzağı doğmuştur. İnsanlar bu garip doğumu günahlarına bağlamışlardır. ${ }^{112} \mathrm{Bu}$,

\footnotetext{
${ }^{104}$ Ebû Zer, Künûz, 1/141.

${ }^{105}$ Ebû Zer, Künûz, 1/148.

${ }^{106}$ Ebû Zer, Künûz, 1/161.

${ }^{107}$ Ebû Zer, Künûz, 1/165-166.

${ }^{108}$ Halep beldelerinden biri olan Sermîn, Sâm b. Nuh'un torunu Sermîn'e nispetle isimlendirilmiştir. Eskiden büyük bir şehir idi. Daha sonraları ise sadece İsmâilîlerin oturduğu bir yer haline geldi. Ebû Abdillah Şihâbüddîn Yâkūt b. Abdullah el-Bağdâdî Yâkūt el-Hamevî, Mu'cemü'l-büldân (Beyrut: Dâru Sâdır, 1977), 3/215.

${ }^{109}$ Ebû Zer, Künûz, 2/208.

${ }^{110}$ Ebû Zer, Künûz, 1/171.

${ }^{111}$ Ebû Zer, Künûz, 1/173.

${ }^{112}$ Ebû Zer, Künûz, 1/166.
} 
Atmaca, Memlükler Dönemi Tarih Yazımına Bir Örnek: Ebû Zer Sıbt İbnü’l-Acemî (ö. 884/1480) ve ...

insanların, başlarına gelen afet ve salgın hastalıklara olduğu gibi anormal doğumlara da günahlarının sebep olduğunu düşündüklerini göstermektedir.

\section{2. İkinci Cilt / Havâdis ve Vefeyât}

İslâm tarih yazıcıllğında umumî tarih ve biyografi türü telif geleneği asırlarca gelişmiş, Memlükler döneminde ise bu iki türün karışımından oluşan "el-havâdis ve'l-vefeyât" çalışmaları tarihçilerin en çok tercih ettiği tür haline gelmiştir. Bu eserlerde farklı bir sistem deneyenler bulunsa da genel olarak senelere göre havâdis, ardından o yıl vefat edenlerin isimleri ve onlara dair bilgilerin bulunduğu vefeyât kısmı bulunmaktadır. ${ }^{113}$ Künûz'un havâdis ve vefeyât kısmının bulunduğu ikinci cildi önce alfabetik olarak evâil bilgilerinden -ki bu konu daha sonra ele alınacaktır- sonra da 802-843 (1399-1440) yılları arasında görev yapmış olan otuz Halep nâibinden ve onların dönemlerinde yaşanan siyasî olaylardan bahsetmektedir. ${ }^{114}$ Buradaki bilgiler Ebû Zer'in bizzat müşahede ettiği veya müşahede edenlerden dinledikleri olduğu için oldukça kıymetlidir.

842 (1438-39) yılı itibarıyla kronolojik olarak yaklaşık 20 yıllık bir Halep tarihini yazan müellif daha çok Halep'te yaşanan siyasî gelişmelere, isyanlara, tayinlere ve yılın sonunda da ölen bazı kişilerin bilgisine yer vermektedir. Olayları yalnızca yıl veya ay değil günü gününe kaydetmiştir. Buradaki vefeyât kısmı genellikle hacimlidir. Vefeyât bilgileri Halep'te görev yapan kişiler ve bu görevlerin mahiyeti, hatta Mekke'de görevlendirilen kadılar ${ }^{115}$ hakkında zengin malumat sunmaktadır. Mesela Ebû Zer'in, hocası İbn Hatîb'in Halep kadılığından azledilmesi hakkında anlattıkları başka kaynaklarda bulunmayan detaylardır. ${ }^{116}$ Halep'te görev yapan kadıların bir gününü nasıl geçirdiğine dair bilgilere ulaşmak da mümkündür. Mesela İbn Hatîb'in görevden alınması nedeniyle göreve atanan İbnü'l-Harzî̀nin Halep'e gelişi, göreve başlayışı, gününü nasıl geçirdiği gibi pek çok detay eserde yer almaktadır. ${ }^{117} \mathrm{Bu}$ kitabın hıtat kısmında medreseler ve buradaki müderrislerden bahsetse de bu konulara dair bilgiler vefeyât kısmında da fazladır.

Havâdis kısmında yalnızca devletin içindeki meseleler değil dış devletlerle ilişkilere dair de malumat bulunmaktadır. Merkezî idarenin yaşadığı problemler, Timur (ö. 807/1405) gibi dış güçlerle mücadeleler, dönemin sultanı ile Şahruh arasında geçen meseleler, ${ }^{118}$ devletlere gönderilen elçiler, ${ }^{119}$ silsile halinde yaşanan depremler ${ }^{120}$ gibi konular bu kısımda yer almaktadır. Bu konular

\footnotetext{
${ }^{113}$ Kortantamer, "Memlûk Tarihçiliğine Genel Bir Bakış", 31-32.

${ }^{114}$ Ebû Zer, Künûz, 2/108-142.

${ }^{115}$ Ebû Zer, Künûz, 2/177.

${ }^{116}$ Ebû Zer, Künûz, 2/144-145; Sehâvî, ed-Dav'ü'l-lâmi', 5/303-307; İbnü'l-İmâd, Şezerâtü'z-zeheb, 9/359-360.

${ }^{117}$ Ebû Zer, Künûz, 2/146.

${ }^{118}$ Ebû Zer, Künûz, 2/172.

${ }^{119}$ Ebû Zer, Künûz, 2/207.

${ }^{120}$ Ebû Zer, Künûz, 2/226.
} 
Atmaca, An Example of Historiography in the Mamluk Period: Abu Zar Sibt Ibn al-Acami (ö. 884/1480) and ...

arasında Mekke Hanbeli kadısının Şahruh ile olan yakın ilişkisi ve Timur'un kemiklerini Mekke'deki Muallâ Kabristanı'na defnettirdiğine dair itham dikkat çekicidir. Bu ithamda bulunanların Mekke Hanbeli Kadısının düşmanları olduğu ve bu haberlerden sonra kadının Şahruh ile ilişkilerine dikkat ettiği ifade edilmiştir. Timur'un Semerkant'ta defnedildiği bilinmektedir. ${ }^{121}$ Konu hakkında araştırma yapanlara bu rivayeti, kadıların mücadeleleri, azledilmeleri için çıkarılan dedikodular gibi yönleriyle incelemeleri tavsiye edilmektedir. ${ }^{122}$

Ebû Zer'in eserinin dikkat çekici yönlerinden biri de tılsımlar, acâib-garâib gibi konuların arasında da Halep'te vefat eden önemli kişilerin özellikle de halife ve sultanların isimleri, bazısı hakkında uzun bazısı hakkında kısa olmak üzere bilgiler vermesidir. Mesela Sultaniyye Medresesi'nde medfûn olan Selahaddîn Eyyûbî’nin (ö. 589/1193) oğlu Melikü'z-Zahir Gazi'yi (ö. 613/1216) tanıttıktan sonra onunla ilgili birçok kişinin daha biyografisini, görevlilerini, döneminin tarihî bilgisinin yanı sıra mutfağında kesilen tavuk sayısını bile zikretmektedir. ${ }^{123}$ Görüldüğü gibi hiç beklenmedik bir yerde ilk ismi zikredilen ve hayatına dair bilgi verileceği anlaşılan kişiden başka birçok kişinin ölümüne de değinilmektedir. Bunun benzeri diğer birçok biyografide de görülmektedir. ${ }^{124} \mathrm{Bu}$ ilâve bilgiler Memlükler döneminin mümtaz biyografi müellifi İbn Hallikân'ın (ö. 681/1282) Vefeyâtü'l-ayyân gibi eseri başta olmak üzere başka eserlerde de bulunmaktadır. ${ }^{125} \mathrm{Bu}$, konunun bütünlüğü açısından faydalı olsa da eserler bütün olarak okunmadığı sürece bilgilerin kaçırılmasına sebep olabilecek bir durumdur.

Künûz'un ikinci cildi evâil ${ }^{126}$ bölümü ile başlamaktadır. Burada Hz. Adem'den itibaren her peygamber ve döneme ait evâil bilgileri alfabetik olarak yer almaktadır. Burada zikredilen canlılar arasında melekler bile yer almıştır. Mesela İsrafil'e ilk secde eden melek olarak yer verilmiştir. Es‘ad b. Zürâre'den (ö. 1/623) Hz. Peygamber'den önce Medine'de ilk namaz kılan, Ebû İshak eş-Ş̂râzî'den (ö. 476/1083) Bağdat'taki Nizâmiyye'de ilk ders veren, Râfi' b. Mâlik'ten (ö. 3/625) ensardan ilk Müslüman olan, Yahya b. Zekeriyya'dan Hz. İsa'ya ilk iman eden kişi olarak bahsedilmektedir. ${ }^{127}$ Ebû

\footnotetext{
${ }^{121}$ İsmail Aka, "Timur”, Türkiye Diyanet Vakfi İslâm Ansiklopedisi (İstanbul: TDV Yayınları, 2012).

${ }^{122}$ Ebû Zer, Künûz, 2/172.

${ }^{123}$ Ebû Zer, Künûz, 1/105-110.

${ }^{124}$ Ebû Zer, Künûz, 1/110-111, 119-125, 128, 130-134.

${ }^{125}$ Eseri bu yönüyle etraflıca inceleyen bir araştırma bulunmaktadır. Detaylı bilgi için bk. Ayaz, "Memlükler Döneminin (648-923/1250-1517) Öne Çıkan Vefeyât, Tabakât ve Terâcim Eserleri”, 6-8.

${ }^{126}$ Evâil, ilklerin anlatıldığı bir edebî türdür. Evâil rivayetlerinin büyük bir kısmının bir konudaki ilkleri bilme uğruna gösterilen çaba sonucu ortaya çıktığı algısı bulunsa da İslâm toplumunda güzel ve hayırlı işlerde önde olmanın değerli görülmesinin bu türe ilgi gösterilmesine etki ettiği düşünülmektedir. Zeynep Orhan - Hüseyin Kahraman, “Evâil Edebiyatı ve Hadis İlmiyle İlişkisi”, Uludağ Üniversitesi İlahiyat Fakültesi Dergisi 21/2 (2012), 243. Evâil türü bazen bir kitap içerisinde ele alınmış, bazen de konuya özel kitaplar kaleme alınmıştır. Kâtip Çelebi evâil ilmini tarihin alt bölümlerinden biri olarak tanımlamıştır. Kâtip Çelebi, Keşfü’z-zunûn, 1/199.

${ }^{127}$ Ebû Zer, Künûz, 2/6-99.
} 
Atmaca, Memlükler Dönemi Tarih Yazımına Bir Örnek: Ebû Zer Sibt İbnü’l-Acemî (ö. 884/1480) ve ...

Zer, evâil bilgilerini verdikten sonra Hz. Peygamber'in, kendisinin ilklerine dair hadislerini aktarmaktadır. Ebû Zer'in evâile yer vermesi hem Memlükler dönemi Şamlı tarihçilerin bu türe ilgi duyması hem de edebiyata olan ilgisindendir.

\section{Genel Değerlendirme}

Ebû Zer'in, Künûz adlı eserini kaleme alırken İbnü'l-Adîm öncesi müelliflerin kitaplarını bizzat gördüğü, ondan sonra kaleme alınanları da kaynaklarına eklediği görülmektedir. Ayrıca o, Zehebî (ö. 748/1348) ve Azîmî (ö. 556/110-61[?]) gibi bazı müelliflerin eserlerini isimleriyle zikrederken bazı kaynaklarını sadece müellifin adıyla "kâle fülân" diyerek belirtmektedir. ${ }^{128}$ Mesela Halep'te medfûn olan halife ve sultanlarla ilgili bölümde Zehebî’nin Târîhu'l-i̇slâm'ına, ${ }^{129}$ Eyyûbî hanedanından Melikü'l-Müeyyed Ebü'l-Fidâ'nın (ö. 732/1331) el-Muhtasar fî târîhi'lbeşer'ine ${ }^{130}$ Selçuklu tarihçisi Azîmînnin Târîh'ine, İbnü'l-Adîm'in Buğyetü't-taleb'ine ${ }^{131}$ ve yararlandığ1 diğer eserlere atıfta bulunmaktadır. Ebû Zer'in bu bilgileri onların kitaplarından aldığ görülmektedir. Bu bilgileri verirken bazen cümlenin sonuna eserin adını yazmış, bazen "Zehebî dedi ki" diyerek cümleyi vermiş, bazen de "Azîmînin yazısından naklettim." diyerek kaynağını belirtmiştir. ${ }^{132}$

Müellif, ilk bölümlerde yer alan sosyal hayata ve inanışlara dair bilgilerin arasında konu tarihî bir şahsiyete geldiğinde ondan uzun uzadıya bahsetmektedir. Bu, tarih kitaplarında hiç umulmadık bir yerde farklı bir bilgiye rastlanabileceğinin güzel bir örneğidir. Dönemin birçok tarih eserinde benzer özellikler bulunmaktadır. Meselâ Makrîzî̀nin ve diğer Memlükler dönemi tarihçilerinin eserlerinde bunun gibi konu içlerine serpiştirilmiş bilgi oldukça fazladır. Künûz' da buna örnek olarak bazı kitâbelerden yola çıkılarak Mesleme (ö. 121/739[?])"133 ve Hz. Ali (ö. 40/661) hakkında bilgi verilmesi gösterilebilir. Ebû Zer, Künûz'da Ashâb-1 Kehf dağına yakın bir mescidde İbranice bir kitâbe bulunduğunu ve üzerinde "Mesleme Rum diyarına girdi ve dört kaleyi fethetti." yazdığı bilgisini verdikten sonra uzun bir biçimde Mesleme'nin hayatına, hatta Mesleme'nin söylediği şiirlere yer vermektedir. ${ }^{134}$ Benzer bir şeyi Sıffîn'deki bir duvarda yazılı olan Ali b. Ebî Talib'in sözlerinden bahsederken de yapmış, bu sözleri aktardıktan sonra Sıffîn'le ilgili bazı beyitlere yer vermiştir. Bu

\footnotetext{
${ }^{128}$ Ebû Zer, Künûz, 1/113.

${ }^{129}$ Ebû Zer, Künûz, 1/108.

${ }^{130}$ Ebû Zer, Künûz, 1/113-115.

${ }^{131}$ Ebû Zer, Künûz, 1/119.

${ }^{132}$ Ebû Zer, Künûz, 1/119.

${ }^{133}$ Burada bahsedilen Mesleme, Emevîler döneminde Anadolu fetihlerinde İslâm ordularını komuta eden, Abdülmelik b. Mervân'ın oğlu olan Mesleme b. Abdülmelik'tir.

${ }^{134}$ Mesleme hakkında kitabın ilk kısımlarında Halep’te vefat eden önemli kişilerden bahsettiği yerde de bilgi vermektedir. Ebû Zer, Künûz, 1/119.
} 
şiirleri İbnü'l-Adîm'den nakleden Ebû Zer, onların Kûfeli meşhur edebiyat âlimi İbn Firnâs (ö. 395/1004) ve Hâkim en-Nîsâbûrînnin (ö. 405/1014) kitaplarından alındığı bilgisini de vermiştir. ${ }^{135}$

Ebû Zer, kendi yaşadığı dönemde Halep'te etkisini gösteren ve kendisinin de şahit olduğu tâunda çok kişinin hayatını kaybettiğini belirttikten sonra daha önce de yaptığı gibi vefeyât bilgilerine yer vermektedir. ${ }^{136}$ Dolayısıyla onun eserinde yalnızca havâdis ve vefeyâtın yer aldığı ikinci ciltte değil, diğer bölümlerde de vefat eden şahıslara dair bilgilere ulaşmak mümkündür. Eserde gerek bu bölümde gerekse diğer bölümlerde vefat eden veya hakkında bir şeyler söyleyeceği kişilerin isimleri neşredenler tarafından koyu renk olarak yazıldığından bu bilgilerin tespiti kolaylaşmıştır.

Ebû Zer, "kultü/dedim ki” ifadesi ile müşahedelerini veya görenlerden dinlediklerini yazmıştır. Mesela müesseselerle ilgili başkalarından aktardığı bilgileri yazdıktan sonra kendi şahsî gözlemlerine "dedim ki” diyerek başlar. Bu, kendi görüşlerini ve müşahedelerini verdiği şeklinde düşünülse de bazen gördükleri değil görenlerden duyduklarını da aynı şekilde aktarmaktadır. Mesela bir medreseden bahsettiği bir yerde “kultü/dedim ki” dedikten sonra Timur'un Halep'e gelişi sırasında bu medresenin harap hale geldiğini söylemiştir. ${ }^{137}$ Halbuki Ebû Zer, Timur'un Halep'e girişinden $(801 / 1399)^{138} 17$ yll sonra dünyaya gelmiştir.

Künûzü'z-zeheb'in birinci cildinin sekizinci bölümü tamamen el-'acâib ve'l-garâibe hasredilmiştir. Müellifin bu unsurlara yer vermesi kendi şahsî tercihi değil yukarıda da bahsedildiği gibi dönemin okuyucusunun talebi nedeniyledir. Bu bölümde olağanüstü pek çok doğumdan, gökyüzü olaylarından, birçok insanın ölümüne sebep olan deprem ve salgınlardan bahsedilmektedir. Ancak şu da belirtilmelidir ki eserde her ne kadar bu konular için ayrı bir bölüm bulunsa da eserin herhangi bir yerinde de el-'acâib ve'l-garâibe dair bilgilerle karşılaşılması mümkündür. Dolayısıyla bu konular hakkında araştırma yaparken eserin bir bütün olarak okunup değerlendirilmesi önem arz etmektedir.

Künûz'un, İbnü'l-Adîm'in Buğyetü't-taleb'inin zeylinin zeyli olduğu daha önce belirtilmişti. İbnü'l-Adîm'in eserinde de el-'acâib ve'l-garâibe dair bir bölüm bulunmaktadır. Ancak onun anlattıkları tılsımlı sütunlar, şifalı sular gibi bilgilerdir. Garip doğumlar bunlar arasında yer almamaktadır. ${ }^{139}$ Ebû Zer, İbnü’l-Adîm sonrası kaynaklardan yararlanarak bu konuyla ilgili çok fazla örnek vermiştir. Bu sırada bazen kaynakları açıkça belirtirken bazen sadece "dedi ki” diyerek

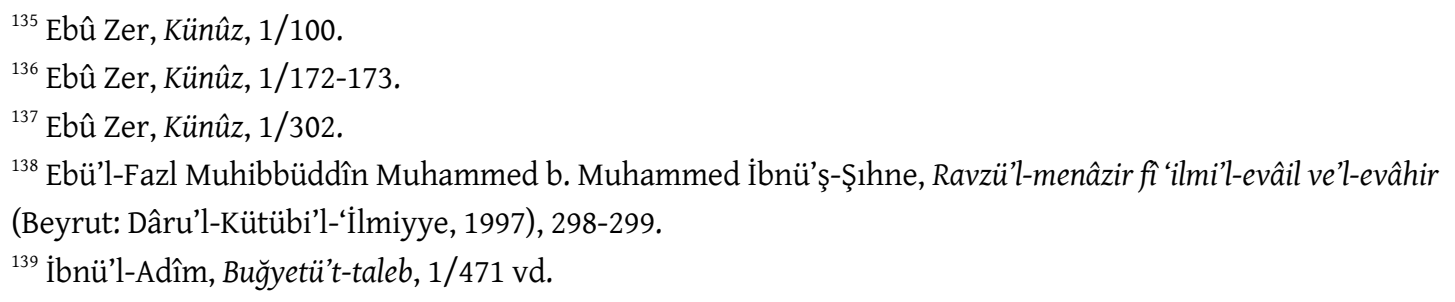


Atmaca, Memlükler Dönemi Tarih Yazımına Bir Örnek: Ebû Zer Sibt İbnü’l-Acemî (ö. 884/1480) ve ...

kaynağı net bir şekilde vermemiştir. Benzer şekilde Makrîzînin Hıtat'ında da el-'acâib ve'l-garâibe dair bir bölüm yer almaktadır. Ancak o da garip doğumları bu bölüm içerisinde değerlendirmemiştir. ${ }^{140}$ Künûz, el-'acâib ve'l-garâib bölümüne dâhil ettiği konular bakımından İbnü'l-Adîm'den ve Makrîzî'den ayrılmaktadır. Ebû Zer'in Künûz'undaki gerek özel bir bölümde ele alınan gerekse diğer kısımlarda yer verilen el-'acâib ve'l-garâibler, genelde Memlükler özelde de Halep halkbilimi çalışmaları için oldukça değerlidir. Eser bu yönüyle özel bir çalışmaya konu olacak malzemeler içermektedir.

Ebû Zer, kendisine ulaşan tarihî bilgileri gerektiğinde tashih etmiştir. Mesela 18 Muharrem 853'te (13 Mart 1449) Humus ehlinden bir adam İbn Hacer'in vefat ettiği haberini vermiş, sonra Kahire'den Hanefî Kadısının haberi gelmiş ve onun Zilhicce'nin on sekizinci günü öldüğü bildirilmiştir. Ebû Zer daha sonra bu bilgiyi tashih etmiş ve bulduğu bir yazıda İbn Hacer'in 28 Zilhicce 852'de (22 Şubat 1449) vefat ettiğinin yazılı olduğunu söylemiştir. ${ }^{141} \mathrm{Bu}$ bilgiler ile Kahire'den Halep'e bir şahsın ölüm bilgisinin 20 gün kadar uzun bir sürede geldiği sonuçlarına da ulaşılmaktadır.

Ebû Zer, eserinde sık sık şahıslar veya olaylar hakkındaki beyitlerine yer vermiştir. Onun edebî yönü burada kendini göstermektedir. Mesela Sermîn Kadısı İmâdüddîn'in azledilmesi konusunda önce kendi beyitlerini sonra da başkalarının konu hakkındaki beyitlerini paylaşmıştır. ${ }^{142}$ Bazen de vefat bilgisini verdiği şahsa ait beyitlere yer vermiştir. ${ }^{143}$

Ebû Zer, 858 (1454) yılı havâdisinden bahsederken Şevval ayında Ebû Abdullah Muhammed b. Ebi'l-Abbas el-Lahmî el-Gırnatî̀nin Şam'ın sahil tarafında vefat ettiğini söylemiş ve 833 (142930)yılındayken evâil bilgilerini ondan aldığını eklemiştir. ${ }^{144}$ Dolayısıyla eserin bir bölümündeki bilgilerin kaynak bilgisine bir başka bölümünde ulaşılması mümkündür.

\section{Sonuç}

Memlükler döneminde başkent Kahire'nin yanı sıra Dımaşk ve Halep'te de önemli âlimler yetişmiş ve bu âlimler günümüze kadar ulaşan pek çok eser kaleme almışlardır. Halep’te yetişmiş önemli simalar arasında Ebû Zer Sıbt İbnü'l-Acemî el-Halebî ve burada kaleme alınmış eserler arasında onun Künûzü'z-zeheb fî târîhi Haleb adlı eseri de bulunmaktadır. Ebû Zer'in Halep tarihine dair zeyl mahiyetinde kaleme aldığı bu eserde dönemin idarî, sosyal, kültürel hayatına dair pek çok

\footnotetext{
${ }^{140}$ Makrîzî, garip doğumlarla ilgili konulara Kitâbü’s-Sülûk li márifeti düveli’l-mülûk adlı eserinde ise çokça yer vermiştir. Buna dair tespitler için bk. Kortantamer, "el-'Acâib ve'l-Garâib”.

${ }^{141}$ Ebû Zer, Künûz, 2/219.

${ }^{142}$ Ebû Zer, Künûz, 2/145.

${ }^{143}$ Ebû Zer, Künûz, 1/117.

${ }^{144}$ Ebû Zer, Künûz, 2/266.
} 
Atmaca, An Example of Historiography in the Mamluk Period: Abu Zar Sibt Ibn al-Acami (ö. 884/1480) and ...

kıymetli bilgiye ulaşılabilmektedir. Bu eserin birinci cildi hıtat, ikinci cildi havâdis ve vefeyât ağırlıklı olup Memlükler dönemi eserlerinde göze çarpan evâil, el-'acâib ve'l-garâib gibi unsurlar da özel bölümler içerisinde yer almıştır. Halkın tılsımlı olduğuna inandığı mekânlar ve cisimlerden de uzun uzadıya bahsetmektedir. Bu hususların tarih kitaplarında bu kadar yer alması yalnızca bu eserin değil Memlükler dönemi tarih eserlerinin büyük çoğunluğunun genel özelliklerindendir. Memlükler döneminde kaleme alınan tarih kitapları sadece geleceğe not düşmek adına değil, gününün insanının okuması amacıyla da kaleme alınmışlardır. Bu yüzden tarihî olaylar içerisinde dikkat çekici bu tarz bilgiler çokça yer almaktadır. Ebû Zer'in Künûz'u da bu eserlerin güzel bir örneğini sunmaktadır. Bu eserde çift başlı doğan bebeklerden, siyam ikizlerinden ve bu ikizlerin ameliyat ile ayrılmasından, yılan ve akreplerle ilgili tılsımlardan birçok bilgiye rastlanmaktadır. Özellikle de siyam ikizlerinin ameliyatla ayrılması konusu oldukça dikkat çekicidir. Çünkü bilim dünyası tarafından bu ameliyatın ilk örneği İstanbul'da Bizanslı bir hekimin yaptığı ameliyat olarak bilinmektedir. Bu hekimin ayırdığı bebekler hayatta kalamamışlardır. Halbuki Bağdat'ta gerçekleşen ve Ebû Zer'in de aktardığı ameliyat sonrası ikizlerden biri uzun süre hayatına devam edebilmiştir. Hıtat cildindeki el-'acâib ve'l-garâibe dair olan bölümde garip yaradılışlı insanlara dair bilgiler vermesi onun eserini Makrîzînnin Hitat'ı ve İbnü'l-Adîm'in Buğyetü't-taleb'inden ayırmaktadır. Havâdis konusu içerisinde acâiblere yer vermesi yönüyle de eser, Makrîzînin Sülûk'u ile benzerlik arz etmektedir. Eserdeki bu bilgiler Halep halkbilimi araştırmaları için değerlidir. Bu bilgilere eserin herhangi bir yerinde rastlamak mümkün olduğu için konu hakkında araştırma yapacak olanların eseri bütün olarak okumaları tavsiye edilmektedir.

Ebû Zer, kaynaklarını bazen cümle başında bazen de cümle sonunda vermeyi tercih etmiştir. Evâile dair bilgilerde olduğu gibi zaman zaman kitabın bir bölümünde verdiği bilgilerin kaynağını bir başka bölümde açıklamıştır. Bu durum bilginin kaynağını tespiti zorlaştırmaktadır. Ayrıca eserde müellifin edebî yönü de belirgin biçimde görülmektedir. Ebû Zer'in diğer eserleri incelendiğinde hadis ve edebiyat ile daha fazla meşgul olduğu anlaşılmaktadır. Buna rağmen bir tarih eseri kaleme alması dönemin âlimlerinin tarih yazmaya ilgisi ve halkın da tarih kitabı okumaya istekli olmalarındandır.

Ebû Zer'in bu eseri, bizzat şahit olduğu olayları aktarması ve İbn Şeddâd'dan sonra Halep'teki önemli mekânları tanıtan ilk eserlerden olması nedeniyle Halep tarihi çalışmaları için önemlidir. Zira ne Buğyetü't-taleb ne de Dürrü'l-müntehâb bu konulara Ebû Zer kadar yer vermemişlerdir. Künûz, bu yönüyle zeyli olduğu eserlerden ayrılmaktadır. Ayrıca kendi döneminin görevlilerinin atanmalarına ve azledilme sebeplerine detaylarıyla yer vermesi nedeniyle bu konuda çalışanlara faydalı olacak bir eserdir. Medreselerden bahsederken burada ders veren âlimleri, vakıf şartlarını, okutulan dersleri ve kitapları detaylıca tanıtması yönüyle özelde Halep genelde Memlük ilmî hayatına dair yapılacak çalışmalar için vazgeçilmez bir kaynaktır. Netice olarak, Ebû Zer'in Künûzü’z- 
Atmaca, Memlükler Dönemi Tarih Yazımına Bir Örnek: Ebû Zer Sibt İbnü’l-Acemî (ö. 884/1480) ve ...

zeheb fî târîhi Haleb adlı eseri, Halep, Memlükler, Ortaçağ tarihi araştırmacılarının müstağni kalamayacakları bir eserdir.

\section{Kaynakça}

Aka, İsmail. "Timur". Türkiye Diyanet Vakfi İslâm Ansiklopedisi. 41/173-177. İstanbul: TDV Yayınları, 2012.

Atmaca, Esra. Halep’te İlmî Hayat Memlûkler Döneminde (1250-1517). İstanbul: Ensar Neşriyat, 2016.

Ayaz, Fatih Yahya. "Memlükler Dönemi (648-923/1250-1517) Tarih ve Tabakât Eserlerine Dair”. İslâm Tetkikleri Dergisi 10/1 (2020), 147-179.

Ayaz, Fatih Yahya. "Memlükler Döneminde (648-923/1250-1517) Siyer Çalışmaları Safedî̀nin (ö. 764/1363) el-Vâfî Adlı Eserinde Hz. Peygamber’in Hayatı”. Siyer Araştırmaları Dergisi 4 (2018), 11-34.

Ayaz, Fatih Yahya. "Memlükler Döneminin (648-923/1250-1517) Öne Çıkan Vefeyât, Tabakât ve Terâcim Eserleri”. Çukurova Üniversitesi İlahiyat Fakültesi Dergisi 16/2 (2016), 1-38.

Ayaz, Fatih Yahya. Memlükler'de Tarih ve Tarihçiler. Ankara: Türk Tarih Kurumu, 2020.

Bağdatlı İsmail Paşa. Hediyyetü'l-ârifiñ esmâi'l-müellifin ve âsâru'l-musannifîn. 2 Cilt. Beyrut: Dâru İhyâi't-Türasi'l-'Arabî, 1951.

Bayat, Ali Haydar. Tıp Tarihi. İstanbul: Merkezefendi Geleneksel Tıp Derneği, 2010.

Çetin, Altan. "Memlûkler Devleti Tarihi Kaynakları". Ortaçă̆ Türk Tarihi Ana Kaynakları. ed. Altan Çetin. 117-141. İstanbul, 2014.

Düzenli, Aygül - Ayaz, Fatih Yahya. "Memlükler Dönemi Hıristiyan Tarihçileri”. Çukurova Üniversitesi İlahiyat Fakültesi Dergisi 17/2 (2017), 85-102.

Ebû Zer, Sibt İbnü’l-Acemî Muvaffakuddîn Ahmed b. İbrahim. Künûzü’z-zeheb fî târîhi Haleb. thk. Şevki Şa's - Fâlih Bekkûr. 2 Cilt. Haleb: Dâru'l-Kalemi'l-'Arabî, 1996.

Erler, A. vd. "Yapışık İkizler”. Perinatoloji Dergisi 4/2 (1996), 110-112.

Hatiboğlu, İbrahim. “Sıbt İbnü’l-Acemî”. Türkiye Diyanet Vakfi İslâm Ansiklopedisi. 37/85-87. İstanbul: TDV Yayınları, 2009. 
Atmaca, An Example of Historiography in the Mamluk Period: Abu Zar Sibt Ibn al-Acami (ö. 884/1480) and ...

İbn Habîb, Ebû Muhammed Bedrüddîn el-Hasen b. Ömer b. el-Hasen ed-Dımaşkî el-Halebî. Dürretü'leslâk fî devleti'l-Etrâk. 2 Cilt. Kahire: Dâru'l-Kütüb ve'l-Vesâiki'l-Kavmiyye, 2014.

İbn Habîb, Ebû Muhammed Bedrüddîn el-Hasen b. Ömer b. el-Hasen ed-Dımaşkî el-Halebî. Tezkiretü'n-nebîh fi eyyâmi'l-Mansûr ve benîh. thk. Muhammed Muhammed Emîn. Kahire: elHey'etü'l-Misriyyetü'l-'Âmme li'l-Kitâb, 1986.

İbn Kuteybe, Ebû Muhammed Abdullah b. Müslim ed-Dîneverî. el-Ma ârif. thk. Servet Ukkâşe. Kahire: Dâru'l-Me'ârif, 4. Basım, 1992.

İbnü'l-Adîm, Ebü'l-Kâsım Kemâleddîn Ömer b. Ahmed. Buğyetü't-taleb fî târîhi Haleb. 12 Cilt. Beyrut: Dâru'l-Fikr, ts.

İbnü'l-Hanbelî, Ebû Abdullah Radıyyüddin Muhammed b. İbrahim b. Yusuf el-Halebî. Dürrü'l-habeb fi târîhi Haleb. 2 Cilt. Dımaşk: Menşûratu Vizâretü’s-Sekâfe, 1972.

İbnü'l-İmâd, Ebü'l-Felâh Abdülhay b. Ahmed b. Muhammed es-Sâlihî. Şezerâtü'z-zeheb fí ahbâri men zeheb. thk. Abdülkadir Arnâût - Mahmûd Arnâût. 9 Cilt. Beyrut: Dâru İbn Kesîr, 1986.

İbnü'ş-Şıhne, Ebü'l-Fazl Muhibbüddîn Muhammed b. Muhammed. ed-Dürrü'l-müntehâb fî târîhi memleketi Haleb. Dımaşk: Dâru'l-Kitâbi'l-'Arabî, 1984.

İbnü'ş-Şıhne, Ebü'l-Fazl Muhibbüddîn Muhammed b. Muhammed. Ravzü'l-menâzir fî 'ilmi'l-evâil ve'levâhir. Beyrut: Dâru'l-Kütübi'l-'̇llmiyye, 1997.

İpşirli, Mehmet. “Hıtatü'l-Makrîziyye”. Türkiye Diyanet Vakfi İslâm Ansiklopedisi. 17/402-404. İstanbul: TDV Yayınları, 1998.

Kâtip Çelebi. Keşfü’z-zunûn. thk. Şerefettin Yaltkaya. 2 Cilt. Ankara: Milli Eğitim Bakanlığı, 1941.

Kortantamer, Samira. "Memlûk Tarihçiliğinde Bir Üslup Unsuru el-'Acâib vel-Garâib". Tarih Incelemeleri Dergisi 9/1 (01 Haziran 1994), 69-87.

Kortantamer, Samira. "Memlûk Tarihçiliğine Genel Bir Bakış". Tarih İncelemeleri Dergisi 1/1 (01 Haziran 1983), 31-35.

Makrîzî, Ebü'l-Abbas Takıyyüddin Ahmed b Ali b Abdülkadir. el-Mevâ'iz ve'l-i'tibâr bi zikri'l-hıtat ve'lâsâr. thk. Muhammed Zeynühüm - Medîha Şerkâvî. 3 Cilt. Kahire: Mektebetü Medbûlâ, 1998.

Orhan, Zeynep - Kahraman, Hüseyin. "Evâil Edebiyatı ve Hadis İlmiyle İlişkisi”. Uludağ Üniversitesi İlahiyat Fakültesi Dergisi 21/2 (2012), 229-244. 
Atmaca, Memlükler Dönemi Tarih Yazımına Bir Örnek: Ebû Zer Sıbt İbnü’l-Acemî (ö. 884/1480) ve ...

Öngül, Ali. "Ebû Zer el-Halebî”. Türkiye Diyanet Vakfi İslâm Ansiklopedisi. 10/269. İstanbul: TDV Yayınları, 1994.

Sehâvî, Şemseddîn Muhammed b. Abdurrahman. ed-Dav'ü'l-lâmi' li ehli'l-karni't-tâsi'. 12 Cilt. Beyrut: Dâru'l-Ĉ̂l, 1992.

Sevim, Ali. "Buğyetü't-taleb”. Türkiye Diyanet Vakfi İslâm Ansiklopedisi. 6/361-362. İstanbul: TDV Yayınları, 1992.

Süyûtî, Ebü’l-Fazl Celâlüddîn Abdurrahman b. Ebî Bekr. Nazmü'l-'ikyân fî a'yâni'l-a'yân. Beyrut: elMektebetü'l-İlmiyye, ts.

Tomar, Cengiz. “Tarih (Mısır, Suriye ve Filistin)”. Türkiye Diyanet Vakfi İslâm Ansiklopedisi. 40/40-45. İstanbul: TDV Yayınları, 2011.

Yâkūt el-Hamevî, Ebû Abdillah Şihâbüddîn Yâkūt b. Abdullah el-Bağdâdî. Mu'cemü'l-büldân. 5 Cilt. Beyrut: Dâru Sâdır, 1977.

Yiğit, İsmail. "Hıtat". Türkiye Diyanet Vakfi İslâm Ansiklopedisi. 17/401-402. İstanbul: TDV Yayınları, 1998.

Yiğit, İsmail. "Memlukler Dönemi (1250-1517) İlmî Hareketine Genel Bir Bakış”. Türkler Ansiklopedisi 5/ (2002), 748-756.

Yiğit, İsmail. Memlükler. İstanbul: Kayıhan Yayınları, 2008.

Ziriklî, Hayreddîn. el-A'lâm. 8 Cilt. Beyrut: Dâru'l-İlm li’l-Melâyîn, 15. Basım, 2002. 
Atmaca, An Example of Historiography in the Mamluk Period: Abu Zar Sibt Ibn al-Acami (ö. 884/1480) and ...

An Example of Historiography in The Mamluk Period: Abu Zar Sibt Ibn al-Acami (ö. 884/1480) and His Book's Kunuz az-Zahab fi Tarikh Haleb

\section{Dr. Esra ATMACA}

\section{Extended Summary}

The Mamluk period (648-923/1250-1517) is a period when scientific studies peaked. Numerous madrasas were built not only in the capital Cairo, but also in other states such as Damascus and Aleppo, and important scholars were raised. One of these scholars is Abu Zar Sibt Ibn al-Acami, who comes from a family of scholars who have grown up with dozens of scholars. He was born in 818 (1415) in Aleppo and spent most of his life here. He took lessons from the teachers who lived in Aleppo, came here or met in Damascus during his pilgrimage. Abu Zar, who developed especially in the fields of hadith, fiqh, literature and history, wrote many works, most of which have not reached today. The work of Abu Zar, who died in 884 (1480), which is the subject of this article, is Kunuz azzahab work on Aleppo history. This work, written in addition to Durru'l-muntahab, which was written as an addition to the Ibn al-Adîm's (d. 660/1262) Bugyat at-talab, consists of two volumes.

The first volume of Kunuz is dominated and it starts with the fifth chapter since the first four parts of the first volume are missing. According to this, in the fifth chapter, the subjects about love, in the sixth chapter, the buildings, places and objects believed to be enchanted with their places, in the seventh chapter the caliphs and sultans who were buried in and around Aleppo, the eighth chapter, the unfortunate events in Aleppo, in the ninth chapter, the Crusaders. From the tenth chapter, the structure and places of Aleppo have been discussed. It is seen that the author takes the Hitat of Makrizi (d. 845/1442) as an example, except for the first sections in this volume. It must be due to his interest in literature that Abu Zer made a special chapter about love. The eighth chapter of the first volume of Kunuz az-zahab is completely devoted to al-'ajaib va'l-gharaib. The author's inclusion of these elements is due to the request of the reader of the period, not his own personal preference.

The second volume of Kunuz, which includes the al-havadis va'l-vafayat part, firstly mentions the knowledge of the alphabet, then thirty Aleppo naib who served between the years 802-843 (13991440) and the political events that took place in their period. Later, as of 842 (1438-39), the author, who wrote a 20-year history of Aleppo chronologically, mostly includes the political developments, riots, appointments and the information of some people who died at the end of the year. He recorded events by day, not just the year or month. The information about faith here is usually voluminous. The information here is very valuable as it is what Abu Zar personally observed or 
Atmaca, Memlükler Dönemi Tarih Yazımına Bir Örnek: Ebû Zer Sibt İbnü’l-Acemî (ö. 884/1480) ve ...

listened to from those who observed. In this work, many valuable information about the administrative, social and cultural life of the period can be reached. In Kunuz, elements such as avail, al-'ajaib val-gharaib, which stand out in the works of the Mamluk period, were also included in special sections. The fact that these issues take place in history books this much is valid not only for this work but also for the historical works of the Mamluk period. The history books written during the Mamluk period were written not only to note the future, but also for the people of the day to read. Therefore, such remarkable information is included in historical events. Abu Zar's Kunuz also provides a good example of these works. In this work, there is a lot of information about babies born with double heads, Siamese twins and the surgical separation of these twins, and talismans about snakes and scorpions. The surgical separation of Siamese twins is particularly striking. Because the first example of this surgery is known by the scientific world as the surgery performed by a Byzantine physician in Istanbul. Babies allocated by this physician did not survive. However, one of the twins survived for a long time after the surgery, which took place in Baghdad and reported by Abu Zar. Although this work has been taken as an example from previous historians in general terms, it differs from the works of the leading Mamluk historians and Aleppo historians in some aspects. The fact that he gives information about people of strange nature distinguishes his work from Makrizi's Hitat and Ibnu'l-Adim's Bugyat at-talab. This information in the book is valuable for Aleppo social science research. It is possible to find this information anywhere in the work.

Keywords: History of Islam, Medieval, Mamluks, Aleppo, Abu Zar Sibt Ibn al-Acami, Kunuz azZahab. 
Atmaca, An Example of Historiography in the Mamluk Period: Abu Zar Sibt Ibn al-Acami (ö. 884/1480) and ... 